\title{
Comprehensive Analysis of Metal Deformation Law Based on Numerical Simulation of Cold Rolling Process
}

\section{Zhu-Wen Yan}

Nanjing Institute of Technology

\section{Bao-Sheng Wang}

Nanjing Institute of Technology

He-Nan Bu ( $\sim$ buhenan_neu@163.com )

Jiangsu University of Science and Technology

Hao Li

Nanjing Institute of Technology

Lei Hong

Nanjing Institute of Technology

Dian-Hua Zhang

Northeastern University

\section{Research Article}

Keywords: 3D elastic-plastic FEM, work roll deflection, lateral thickness, flatness regulation effect, rolling pressure

Posted Date: December 29th, 2020

DOI: https://doi.org/10.21203/rs.3.rs-128878/v1

License: (c) (1) This work is licensed under a Creative Commons Attribution 4.0 International License. Read Full License 


\title{
Comprehensive Analysis of Metal Deformation Law Based on Numerical
}

\section{Simulation of Cold Rolling Process}

\author{
Zhu-Wen Yan ${ }^{1}$, Bao-sheng Wang ${ }^{1}$, He-nan $\mathrm{Bu}^{2 *}$, Hao $\mathrm{Li}^{1}$, Lei Hong ${ }^{1}$, Dian-hua Zhang ${ }^{3}$ \\ ${ }^{1}$ Jiangsu Provincial Engineering Laboratory of Intelligent Manufacturing Equipment, Industrial Technology Research Institute of \\ Intelligent Equipment, Nanjing Institute of Technology, Nanjing 211167, Peoples R China. ${ }^{2}$ School of Mechanical Engineering, Jiangsu \\ University of Science and Technology, Zhenjiang 212003, Peoples R China. *email: buhenan_neu@ 163.com. ${ }^{3}$ Northeastern University, \\ State Key Laboratory of Rolling and Automation, 3-11 Wenhua Road, Shenyang, Peoples R China
}

\begin{abstract}
Through taking the cold rolling process as the research object, the three-dimensional finite element model of the strip rolling process is established by using ANSYS/LS-DYNA software. The simulation results of the finite element model have a good fit with the actual production data. The rolling process is dynamically simulated, and the distribution curves of important rolling parameters such as equivalent stress, control efficiency coefficient, transverse rolling pressure, lateral thickness and work roll deflection is obtained. The research results of this paper have strong practicability for the process control of cold strip rolling mill. The research results have certain guiding significance for the development and optimization of the rolling control system.
\end{abstract}

Keywords: 3D elastic-plastic FEM; work roll deflection; lateral thickness; flatness regulation effect; rolling pressure 


\section{Introduction}

In the analysis of the cold rolling process, the coupling analysis of the roll elastic flattening deformation and the deformation of strip is required. The elastic-plastic finite element calculation using implicit static iterative algorithm is inefficient. It is not easy to converge when the contact problem of large deformation is analyzed. By using numerical simulation, the size and location of the rolling pressure peak were analyzed by Xiang-hua $\mathrm{Liu}^{[1]}$. For the 6-high continuously variable crown mill, a 3D elastoplastic finite element method (FEM) model was developed by Kezhi Linghu ${ }^{[2]}$. The efficiency factor of the actuators in the work roll bending, intermediate roll bending and intermediate roll shifting of the six-high universal crown control mill (UCM mill) was obtained by Qing-Long Wang ${ }^{[3]}$. Sun Jie analyzed the distribution of rolling pressure and the change rule of lever arm coefficient ${ }^{[4]}$. Because the explicit time integration is used during the calculation process, no iterative solution is needed in the explicit dynamics and the computational efficiency is high. The elastoplastic deformation of the strip during rolling, elastic deflection of the roll, elastic flattening and residual stress after rolling can be considered in the elastoplastic finite element method. Li Hongbo analyzed the profile of the segmented CVC intermediate roll and tested it in industrial production ${ }^{[5]}$. Hyojin Park conducted a 3D coupling analysis of the elastic-plastic deformation of the strip of the rolling mill stand and the elastic deformation of the roll ${ }^{[6]}$. When UCM rolling mill bears different IRS values, Wang Qinglong analyzed the strip rolling process ${ }^{[7]}$. Xing $\mathrm{Lu}$ proposed a dynamic incremental model of chatter in UCM rolling mills ${ }^{[8]}$. An improved approach based on the varying curve of crown ratio, which can give the location of the flatness defect in more detail, is proposed by Qing-Long Wang ${ }^{[9]}$. The finite element method is widely used in the numerical simulation of rolling process. It plays an important role in calculating the rolling process parameters and improving the accuracy of the rolling model. Based on the edge drop control characters established, the control model and the cooperation strategy were designed and applied to the practical production by Xiao chen Wang ${ }^{[10]}$. The finite-element method (FEM) is used to develop the governing equation of motion of the working roll of a four-high rolling mill by Sajan $\mathrm{Kapil}^{[11]}$. A vibration model with two degrees of freedom is proposed for a cold sheet rolling mill and the stiffness parameters of different mill elements are calculated by Masoud Mosayebi ${ }^{[12]}$. Chu han $\mathrm{Wu}$ presents a multi-field analysis of full hydrodynamic lubrication in high speed cold rolling of metal strips ${ }^{[13]}$. In this paper, the simulation of the rolling process with relatively large ratio of width to thickness has been realized. The results are used to provide parameter predictions with reference value to the actual production.

\section{Three-dimensional finite element model establishment}

The method of establishing elastoplastic finite element equation considering inertial force and damping force is called dynamic analysis method ${ }^{[14]}$. The plastic processing engineering load action time is relatively short. The equations of motion including inertial and damping forces should be used ${ }^{[15]}$. When the above second-order differential equations are calculated, the center difference format is used 
to discrete time. Through using principle of dynamic virtual work for elastoplastic problems, the dynamic finite element equation is obtained and it is shown as equation (1).

$$
[M]\{\ddot{u}\}+[C]\{\dot{u}\}+[K]\{u\}=\{P\}-\{F\}
$$

In equation (1), $\{\ddot{u}\}$ is nodal acceleration vector. $\{\dot{u}\}$ is node velocity vector. $\{u\}$ is node displacement vector. $[M]$ is global concentrated mass matrix. $[C]$ is global damping matrix. $[K]$ is stiffness matrix. $\{P\}$ is external force node force vector. $\{F\}$ is internal force nodal force vector.

In order to ensure that the simulation is as close as possible to the actual rolling process, the coupling analysis of the roll system deflection, the roll elastic flattening and the strip elastic-plastic deformation are carried out. The billet has elastoplastic deformation and work hardening during rolling, therefore a bilinear isotropic hardening model is used. The roll body has elastic deformation during rolling, so the isotropic linear material model is used. The roll neck has no deformation during rolling, so the rigid body model is used.
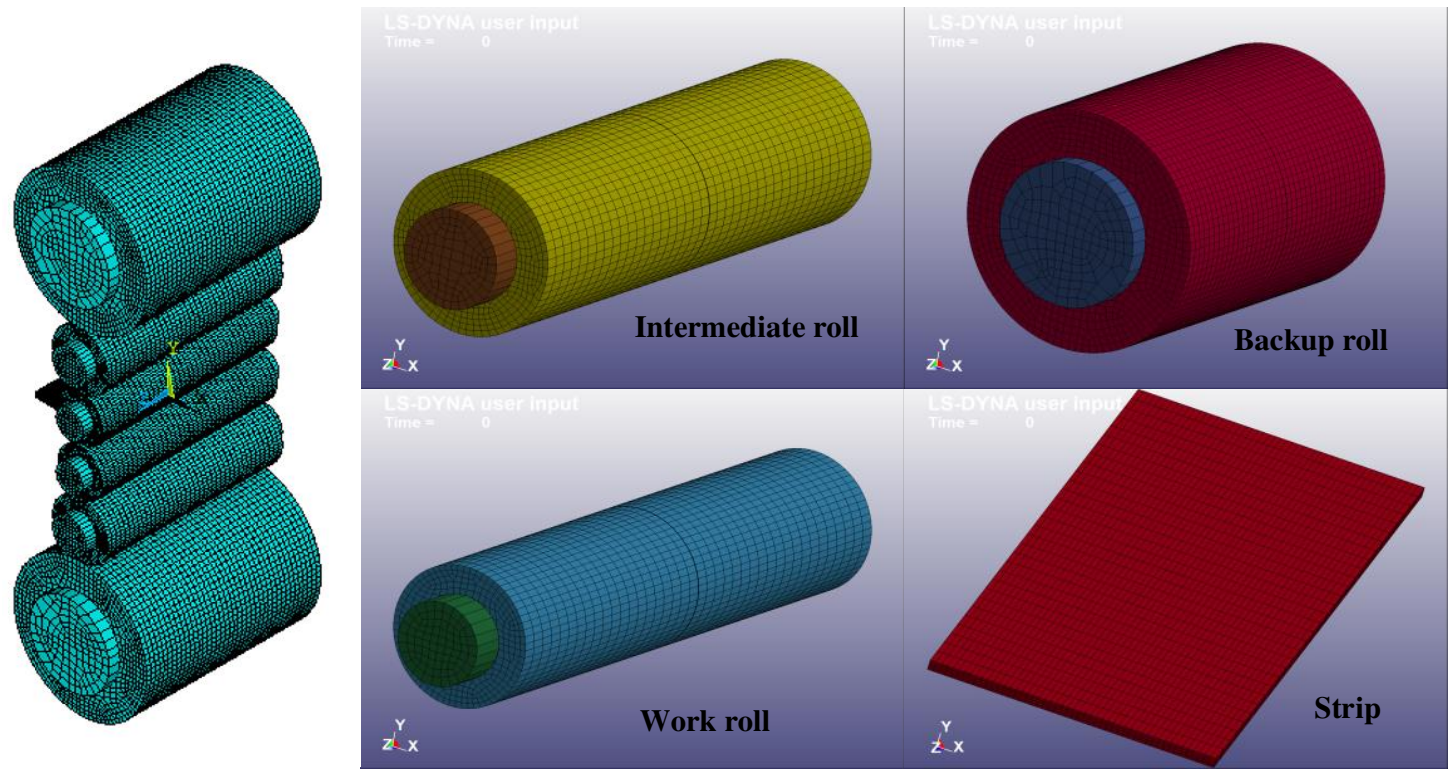

Fig. 1 Three-dimensional finite element model

Fig. 1 is a three-dimensional finite element model. The solid element of SOLOD164 three-dimensional display structure is used for finite element analysis of cold rolling process. The hexahedral mesh is adopted to mesh, and the mesh generation mode is sweep mode. In the finite element model, there are elastomer six roll system, elastoplastic strip and rigid roll neck. In this model, the bending deformation, flattening deformation and strip elastic-plastic deformation of the entire roll system are considered.

\section{Results and discussion}

\subsection{Rolling experiment verification of model accuracy}

The original thickness of the strip used in the verification experiment is $2.8 \mathrm{~mm}$. 
The strip width is $1250 \mathrm{~mm}$. The strip type is SPCC. The rolling process parameters are shown in Table 1.

Table 1 The rolling process parameter table of verification experiment

\begin{tabular}{ccccccc}
\hline $\begin{array}{c}\text { Test } \\
\text { group }\end{array}$ & $\begin{array}{c}\text { Reduction } \\
\text { ratio/\% }\end{array}$ & $\begin{array}{c}\text { Front } \\
\text { tension/MPa }\end{array}$ & $\begin{array}{c}\text { Back } \\
\text { tension/MPa }\end{array}$ & $\begin{array}{c}\text { Work roll } \\
\text { bending/kN }\end{array}$ & $\begin{array}{c}\text { Intermediate } \\
\text { roll bending } \\
/ \mathrm{kN}\end{array}$ & $\begin{array}{c}\text { Intermediate } \\
\text { roll shifting } \\
/ \mathrm{mm}\end{array}$ \\
\hline 1 & 29.17 & 157.13 & 93.57 & 110.00 & 73.51 & 15 \\
2 & 31.47 & 149.35 & 113.63 & 153.71 & 57.13 & 15 \\
\hline
\end{tabular}

Fig. 2 is the comparison between the simulated value and the actual measured value of the lateral thickness distribution of the exit strip. The trend of measured lateral thickness distribution curve is consistent with the trend of the simulated lateral thickness distribution curve. In the verification experiment with a reduction ratio of $29.17 \%$, the absolute error of the measured value and the simulated value does not exceed 21um, and the relative error does not exceed $1 \%$. In the verification experiment with a reduction ratio of $31.47 \%$, the absolute error between the measured value and the simulated value is less than $13 \mathrm{um}$, and the relative error is less than $1 \%$. Therefore, it is reliable to analyze the strip rolling process based on the three-dimensional finite element model of the rolling mill.

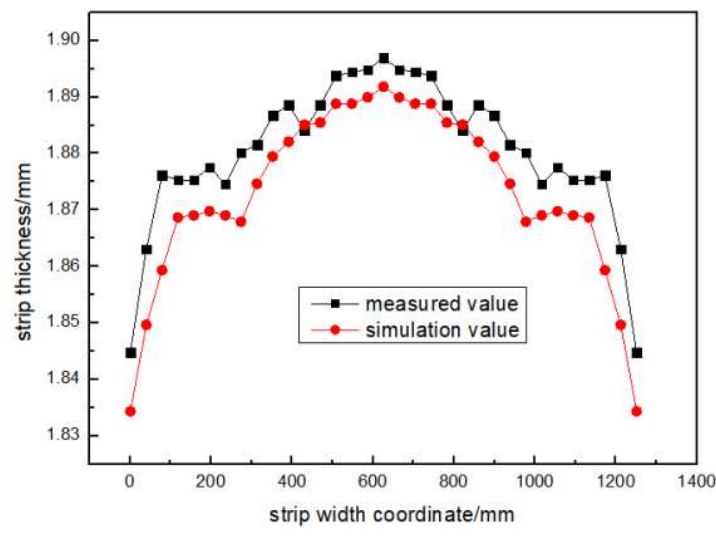

(a) First group

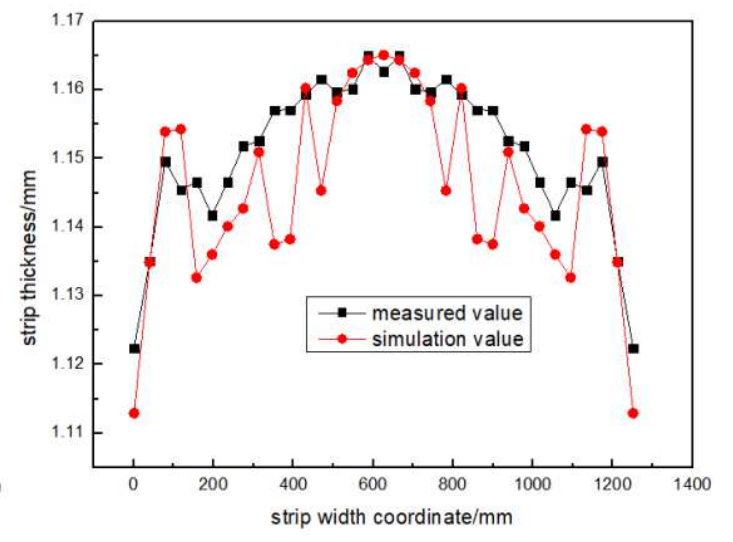

(b) Second group

Fig. 2 Distribution diagram of finite element simulation value and actual measured value of lateral thickness distribution of exit strip

\subsection{Effect of different reductions on equivalent stress}

The simulation experiment parameters of the effect of different reductions on equivalent stress are shown in Table 2.

Table 2 Simulation experiment parameters of influence of reduction on equivalent stress

\begin{tabular}{ccccc}
\hline Test group & Strip specification $/ \mathrm{m}$ & Reduction $/ \mathrm{m}$ & Front tension/MPa & Back tension/MPa \\
\hline 1 & $0.038 \times 1.2$ & 0.00705 & 1.3 & 1.2 \\
2 & $0.038 \times 1.2$ & 0.0105 & 1.3 & 1.2 \\
3 & $0.038 \times 1.2$ & 0.01405 & 1.3 & 1.2 \\
\hline
\end{tabular}

Fig. 3 is the distribution of the equivalent stress of the strip after rolling at different reductions. When the reduction is increased from $0.00705 \mathrm{~m}$ to $0.0105 \mathrm{~m}$, the area of the large equivalent stress area is increased, and the edge of the area extends outwards more gently. At the same time, the area of the second large equivalent stress 
is reduced, and the edge of the area extends outward more gently. When the reduction is increased from $0.0105 \mathrm{~m}$ to $0.01405 \mathrm{~m}$, the area of the large equivalent stress area is increased, and the edge of the area extends more violently. At the same time, the area of the second large equivalent stress is reduced, and the edge of the area extends outward more gently.

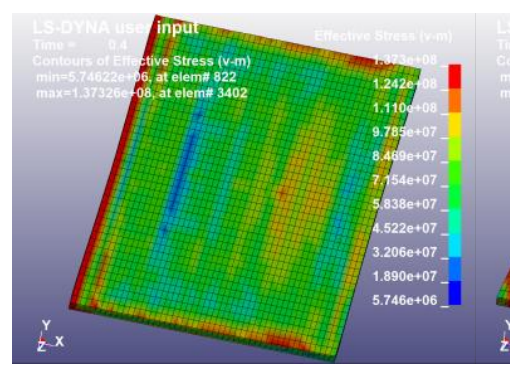

(a) Reduction 0.00705

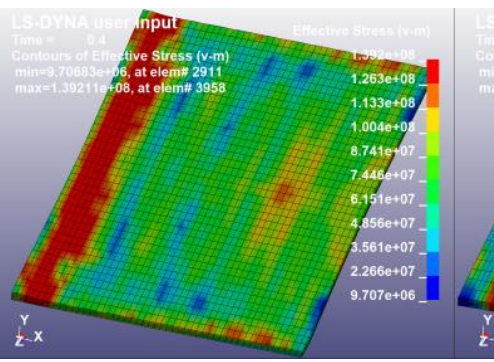

(b) Reduction 0.0105

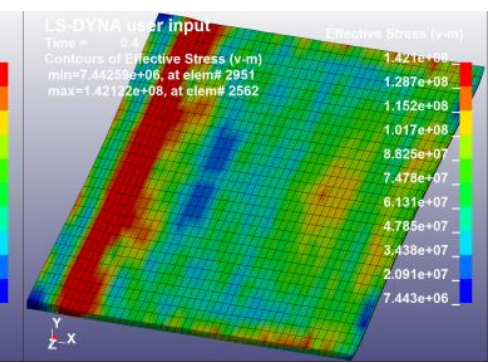

(c) Reduction 0.01405

Fig. 3 Distribution diagram of the equivalent stress of the strip after rolling at different reductions

Fig. 4 is the distribution diagram of the equivalent stress of the work roll after rolling at different reductions. When the reduction is increased from $0.00705 \mathrm{~m}$ to $0.0105 \mathrm{~m}$, the area of small equivalent stress is increased, and the edge of the area extends outwards more gently. At the same time, the area of second small equivalent stress is increased, and the edge of the area extends outwards more gently. When the reduction is increased from $0.0105 \mathrm{~m}$ to $0.01405 \mathrm{~m}$, the area of small equivalent stress is increased, and the edge of the area extends more violently. At the same time, the area of the second small equivalent stress is reduced, and the edge of the area extends more violently.

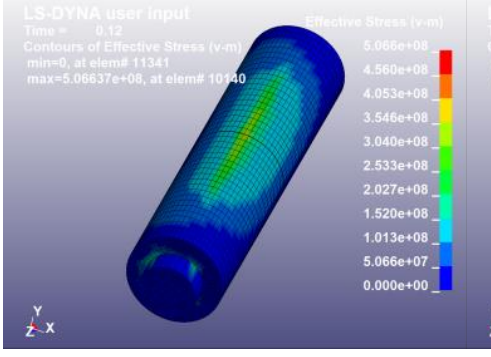

(a) Reduction 0.00705

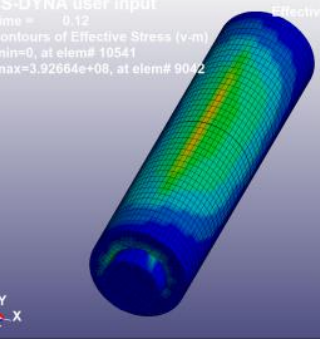

(b) Reduction 0.0105

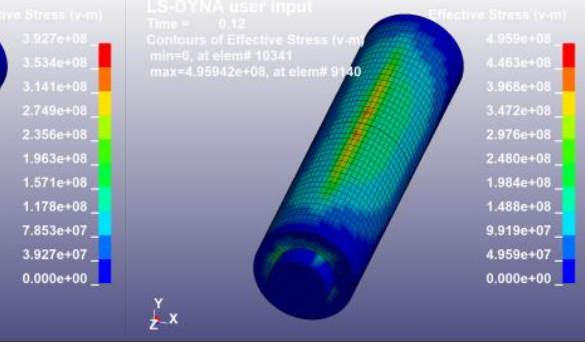

(c) Reduction 0.01405

Fig. 4 The distribution diagram of the equivalent stress of the work roll after rolling at different reductions

Fig. 5 is the distribution of the equivalent stress of the intermediate roll after rolling at different reductions. When the reduction is increased from $0.00705 \mathrm{~m}$ to $0.0105 \mathrm{~m}$, the area of small equivalent stress is reduced, and the edge of the area extends more violently. At the same time, the area of second small equivalent stress is increased, and the edge of the area extends more violently. When the reduction is increased from $0.0105 \mathrm{~m}$ to $0.01405 \mathrm{~m}$, the area of small equivalent stress is reduced, and the edge of the area extends outwards more gently. At the same time, the area of second small equivalent stress is increased, and the edge of the area extends outwards more gently. 


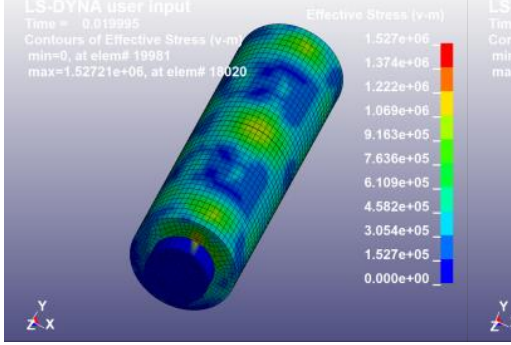

(a) Reduction 0.00705

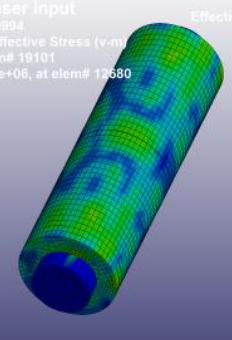

(b) Reduction 0.0105

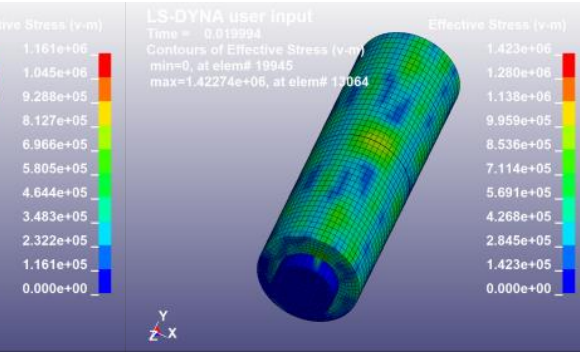

(c) Reduction 0.01405

Fig. 5 Distribution of the equivalent stress of the intermediate roll after rolling at different reductions

Fig. 6 is the distribution of the equivalent stress of the backup roll after rolling at different reductions. When the reduction is increased from $0.00705 \mathrm{~m}$ to $0.0105 \mathrm{~m}$, the area of second small equivalent stress is reduced, and the edge of the area extends outwards more gently. When the reduction is increased from $0.0105 \mathrm{~m}$ to $0.01405 \mathrm{~m}$, the area of second small equivalent stress is increased, and the edge of the area extends more violently.

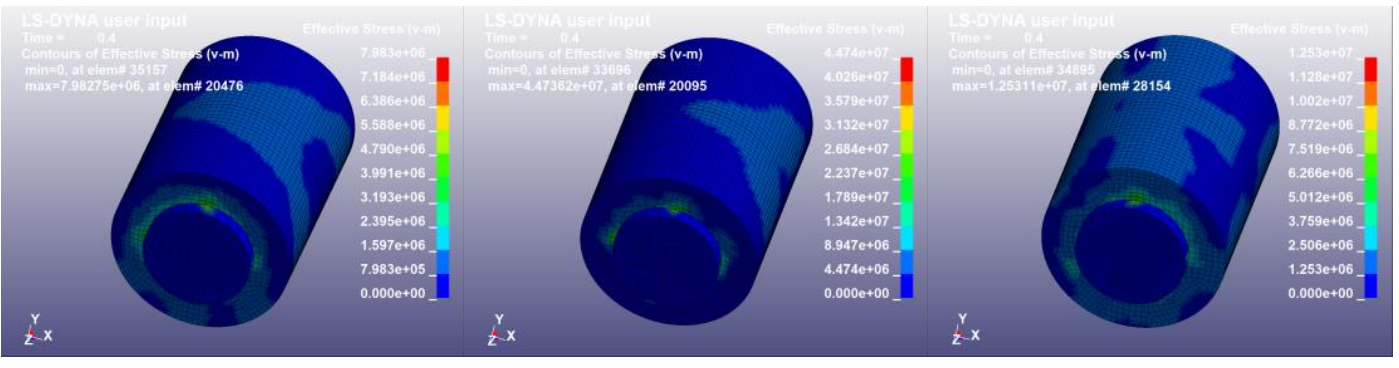

(a) Reduction 0.00705

(b) Reduction 0.0105

(c) Reduction 0.01405

Fig. 6 Distribution of the equivalent stress of the backup roll after rolling at different reductions

\subsection{Analysis of the influencing factors of the regulation efficiency coefficient}

The control efficiency coefficient is analyzed and calculated from the angle of the measured strip shape stress distribution ${ }^{[16]}$. The understanding of the adjustment performance of the flatness control mechanism is no longer limited to the category of the first, second, and fourth flatness deviation. Any flatness adjustment performance can be described [17]. Flatness deviation pattern recognition and decoupling calculation are not required. The flatness control effect is the amount of change in the flatness of the roll gap of the rolling mill along the strip width under the unit adjustment of a flatness control technology. It is shown in equation (2).

$$
E f f_{i j}=\Delta Y_{i} \cdot\left(1 . / \Delta U_{j}\right)
$$

In equation (2), Eff $_{i j}$ is flatness control efficiency coefficient. $i$ is number of measuring points in the strip width direction. $j$ is number of strip flatness adjustment mechanism. $\Delta Y_{i}$ is strip flatness change amount in the $i$ measurement section, $I . \Delta U_{j}$ is adjustment amount of the $j$ strip flatness adjustment mechanism. If the adjustment mechanism is rolling force or bending force, the unit is $k N$. If the adjustment mechanism is the intermediate roll shifting amount or work roll tilting amount, the unit is $\mathrm{mm}$.

The roll is separated into several units. The load on the roll and the elastic 
deformation of the roll are discretized according to the same unit. By applying the concept of influence function in mathematical physics, the deformation caused at various points of the roll body is determined when applying unit force to each unit ${ }^{[18]}$. The deformation value of each unit is obtained by superimposing the deformation caused by each unit when all loads are applied. The influence function of work roll bending force is shown in equation (3).

$$
g_{w f}(i)=\frac{1}{6 E_{w} I_{w}}\left\{x_{i}^{2}\left(3 L_{w}-x_{i}\right)+\left(1+v_{w}\right) D_{w}^{2} x_{i}\right\}
$$

In equation (3), $L_{w}$ is half of the work roll bending hydraulic cylinder center distance, $m m . g_{w f}(i)$ is deflection of the $i$ unit caused by total deformation when a unit force is applied in the center of the work roll hydraulic cylinder, $\mathrm{mm} / \mathrm{kN}$. $E_{w}$ is Young's modulus of work roll, $\mathrm{kN} / \mathrm{mm}^{2} . I_{w}$ is modulus of bending section of work roll, $\mathrm{mm}^{4} . v_{w}$ is work roll Poisson's ratio. $D_{w}$ is work roll diameter, $\mathrm{mm}$. $x_{i}$ is $i$ unit coordinates, $m m$.

\subsubsection{Effect of different strip widths on bending roll efficiency coefficient}

The simulation experiment parameters of the influence of different strip widths on the bending roll efficiency coefficient are shown in Table 3.

Table 3 Simulation experiment parameters of the effect of strip width on bending roll efficiency coefficient

\begin{tabular}{ccccccc}
\hline $\begin{array}{c}\text { Test } \\
\text { group }\end{array}$ & $\begin{array}{c}\text { Strip } \\
\text { width/mm }\end{array}$ & $\begin{array}{c}\text { Front } \\
\text { tension/MPa }\end{array}$ & $\begin{array}{c}\text { Back } \\
\text { tension/MPa }\end{array}$ & $\begin{array}{c}\text { Exit } \\
\text { thickness/mm }\end{array}$ & $\begin{array}{c}\text { Rolling } \\
\text { speed/(m/min) }\end{array}$ & $\begin{array}{c}\text { Reduction } \\
\text { ratio/\% }\end{array}$ \\
\hline 1 & 850 & 95 & 137 & 0.27 & 1100 & 15 \\
2 & 950 & 95 & 137 & 0.27 & 1100 & 15 \\
3 & 1050 & 95 & 137 & 0.27 & 1100 & 15 \\
4 & 1150 & 95 & 137 & 0.27 & 1100 & 15 \\
5 & 1250 & 95 & 137 & 0.27 & 1100 & 15 \\
\hline
\end{tabular}

Fig. 7 is the curve distribution diagram of work roll bending efficiency coefficient at different strip widths. 20 feature points are taken in the width direction. When the strip width is increased, the regulation efficiency coefficient at the edge of the strip is increased. And when the strip width is increased, the regulation efficiency coefficient in the middle of the strip is increased. When the strip width is increased, the control effect of roll bending is enhanced. As the strip width is increased, the control ability of flatness control technology of roll bending is increased, and its regulation characteristics are particularly affected by the strip width. 

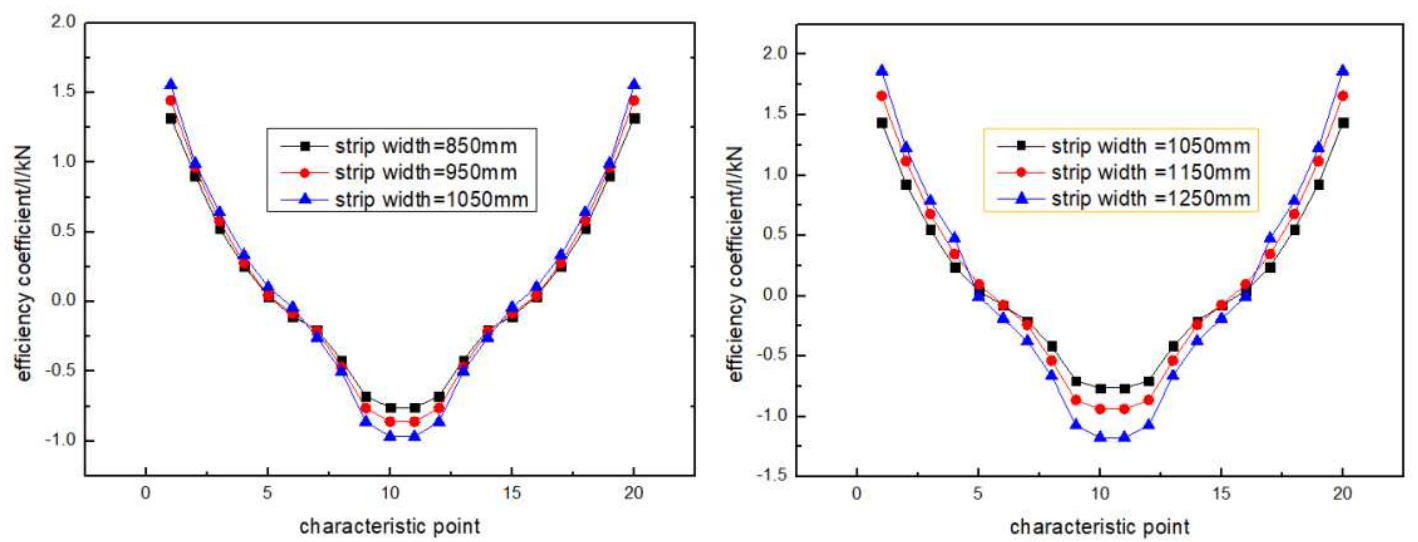

Fig. 7 Curve distribution diagram of work roll bending efficiency coefficient at different strip widths

\subsubsection{Effect of different rolling forces on roll bending efficiency coefficient}

The simulation experiment parameters of the effect of different rolling forces on the roll bending efficiency coefficient are shown in Table 4.

Table 4 The simulation experiment parameters of the effect of different rolling forces on the roll bending efficiency coefficient

\begin{tabular}{ccccccc}
\hline $\begin{array}{c}\text { Test } \\
\text { group }\end{array}$ & $\begin{array}{c}\text { Rolling } \\
\text { force/MN }\end{array}$ & $\begin{array}{c}\text { Front } \\
\text { tension/MPa }\end{array}$ & $\begin{array}{c}\text { Back } \\
\text { tension/MPa }\end{array}$ & $\begin{array}{c}\text { Exit } \\
\text { thickness/mm }\end{array}$ & $\begin{array}{c}\text { Rolling } \\
\text { speed/(m/min) }\end{array}$ & $\begin{array}{c}\text { Reduction } \\
\text { ratio/\% }\end{array}$ \\
\hline 1 & 3 & 75 & 103 & 0.35 & 1000 & 17 \\
2 & 7 & 75 & 103 & 0.35 & 1000 & 17 \\
3 & 11 & 75 & 103 & 0.35 & 1000 & 17 \\
4 & 19 & 75 & 103 & 0.35 & 1000 & 17 \\
5 & 23 & 75 & 103 & 0.35 & 1000 & 17 \\
\hline
\end{tabular}

Fig. 8 is the curve distribution diagram of work roll bending efficiency coefficient at different rolling forces. 20 feature points are taken in the width direction. When the rolling force is less than 11MN, the efficiency coefficient of the roll bending is reduced as the rolling force is increased. When the rolling force is greater than 11MN, the efficiency coefficient of the roll bending is enhanced as the rolling force is increased. When the rolling force is above $19 \mathrm{MN}$, the coefficient of efficiency coefficient of the roll bending remains basically unchanged.
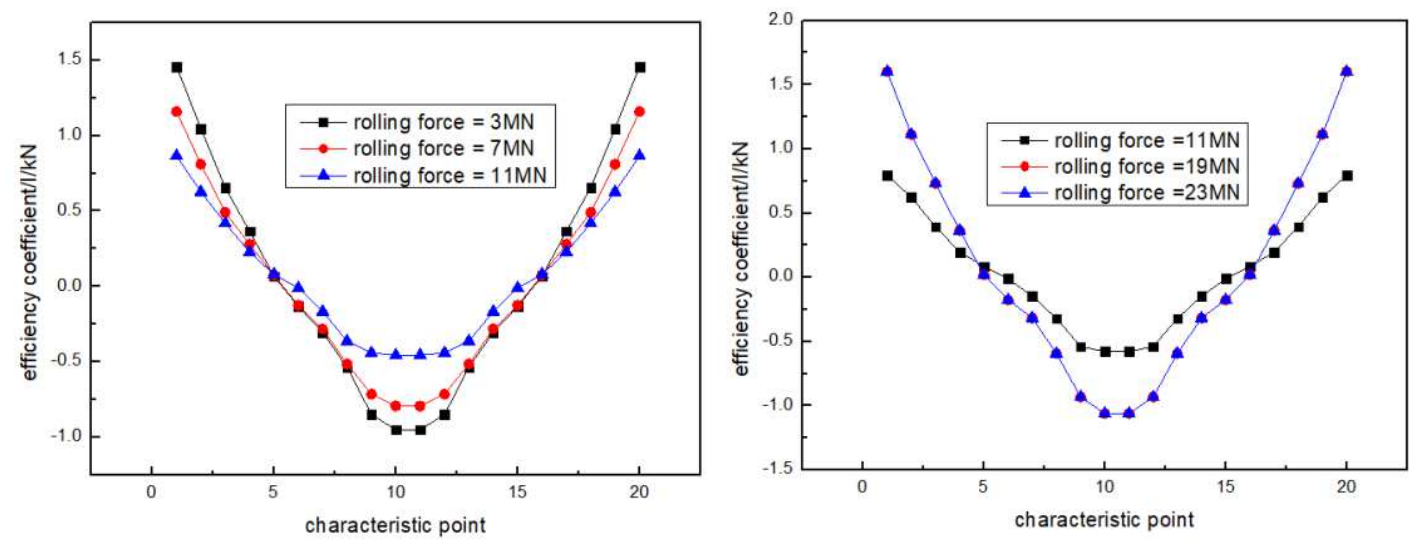

Fig. 8 Curve distribution diagram of work roll bending efficiency coefficient at different rolling forces 


\subsubsection{Efficiency coefficient of different work roll bending force}

The simulation experiment parameters of different work roll bending force adjustment efficiency coefficients are shown in Table 5.

Table 5 Simulation experiment parameters of the effect of work roll bending force on regulating

\begin{tabular}{|c|c|c|c|c|c|}
\hline $\begin{array}{l}\text { Test } \\
\text { group }\end{array}$ & $\begin{array}{l}\text { Work roll } \\
\text { bending/t }\end{array}$ & $\begin{array}{c}\text { Front } \\
\text { tension/MPa }\end{array}$ & $\begin{array}{c}\text { Back } \\
\text { tension/MPa }\end{array}$ & $\begin{array}{c}\text { Rolling } \\
\text { speed } /(\mathrm{m} / \mathrm{min})\end{array}$ & $\begin{array}{c}\text { Reduction } \\
\text { ratio/\% }\end{array}$ \\
\hline 1 & 13 & 83 & 97 & 950 & 23 \\
\hline 2 & 27 & 83 & 97 & 950 & 23 \\
\hline 3 & 31 & 83 & 97 & 950 & 23 \\
\hline 4 & 49 & 83 & 97 & 950 & 23 \\
\hline
\end{tabular}

Fig. 9 is the curve distribution of the efficiency coefficient under different bending force. As the roll bending force becomes larger, the smaller, the control efficiency coefficient at the strip edge becomes smaller, and the control efficiency coefficient in the middle of the strip becomes smaller. At the same time, the control efficiency coefficient curve becomes smoother. The 13t control efficiency coefficient curve is compared with the $27 \mathrm{t}$ control efficiency coefficient curve. The control efficiency coefficient is decreased with the increasing of roll bending force, and it is very obvious.

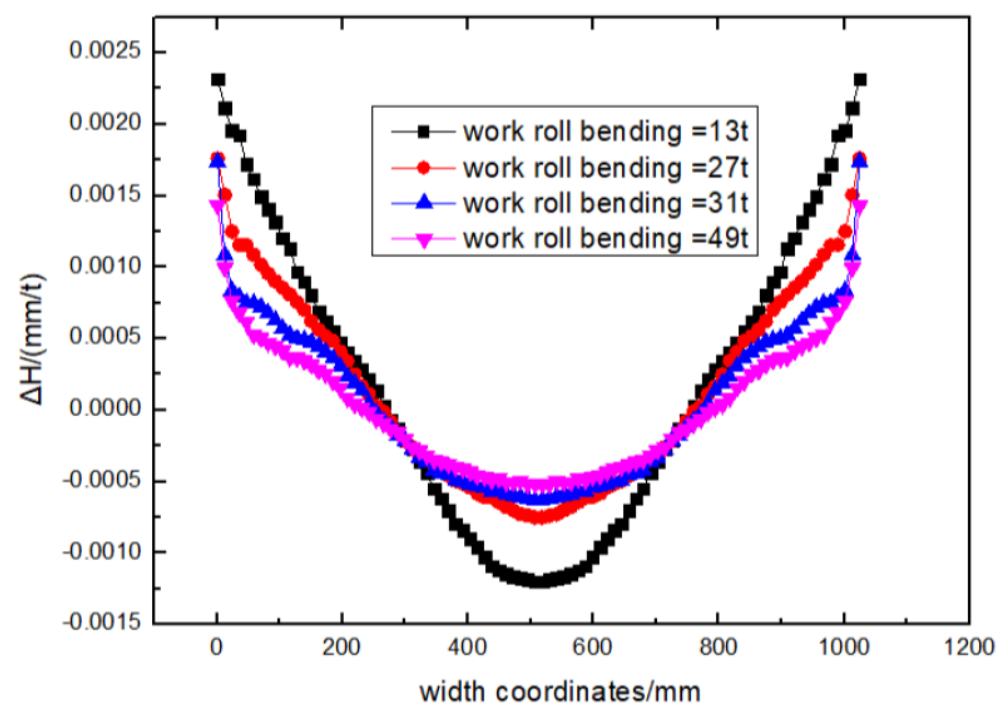

Fig. 9 curve distribution of the efficiency coefficient under different bending force

\subsubsection{Efficiency coefficient of different intermediate roll bending force}

The simulation experiment parameters of adjustment efficiency coefficients under different intermediate roll bending force are shown in Table 6.

Table 6 Simulation experiment parameters of adjustment efficiency coefficients under different intermediate roll bending force

\begin{tabular}{cccccc}
\hline $\begin{array}{c}\text { Test } \\
\text { group }\end{array}$ & $\begin{array}{c}\text { Intermediate roll } \\
\text { bending/t }\end{array}$ & $\begin{array}{c}\text { Front } \\
\text { tension/MPa }\end{array}$ & $\begin{array}{c}\text { Back } \\
\text { tension/MPa }\end{array}$ & $\begin{array}{c}\text { Rolling } \\
\text { speed/(m/min })\end{array}$ & $\begin{array}{c}\text { Reduction } \\
\text { ratio/\% }\end{array}$ \\
\hline 1 & 19 & 93 & 117 & 970 & 13 \\
2 & 27 & 93 & 117 & 970 & 13 \\
3 & 43 & 93 & 117 & 970 & 13 \\
4 & 57 & 93 & 117 & 970 & 13 \\
\hline
\end{tabular}


Fig. 10 is the curve distribution of the control efficiency coefficient under different rolling bending force. The control efficiency coefficient curve of the intermediate roll bending is gradually increased from the middle to the side. The control efficiency coefficient of the intermediate roll bending is also closely related to the size of the roll bending force. As the bending force is increased, the control efficiency coefficient of the intermediate roll bending roll is gradually decreased, and the distribution curve becomes more and more gentle.

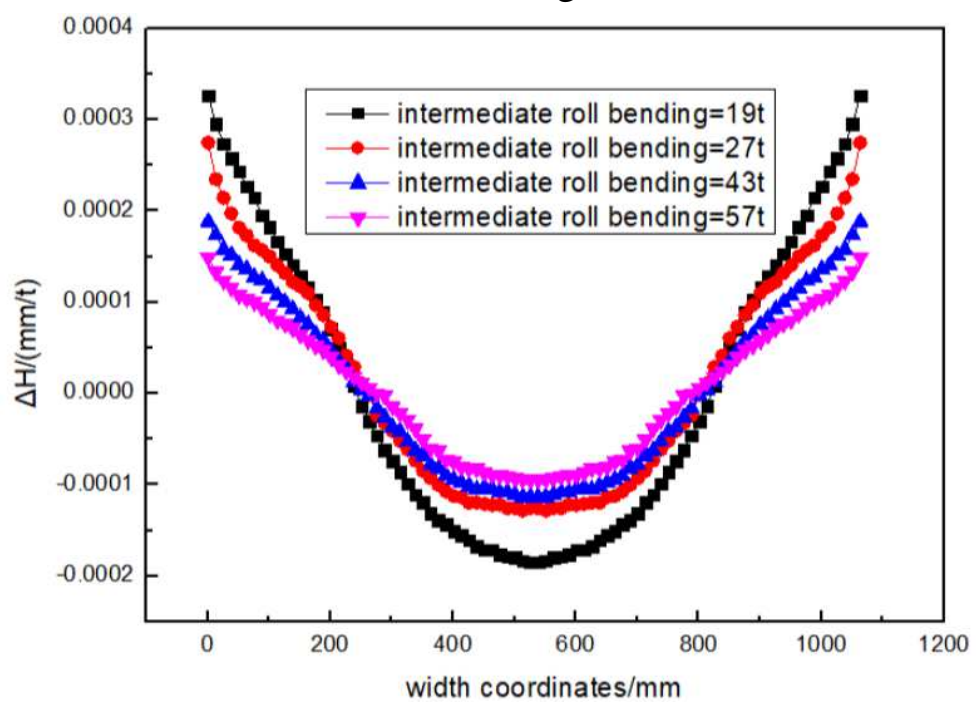

Fig. 10 curve distribution of the control efficiency coefficient under different rolling bending force 2.4 Analysis of influencing factors of rolling pressure distribution along strip width

There is elastic flattening deformation in the roll and the elastic deformation in the strip. The increased part of the deformation zone is not all the plastic zone, and a considerable part is the elastic zone ${ }^{[19 \sim 21]}$. The rolling pressure in the elastic zone is much lower than the rolling pressure in the plastic zone. Due to the elastic recovery of the strip, the strip does not come out from the lowest point after the roll is flattened at the exit, but a distance higher than the lowest point ${ }^{[2224]}$. The rolling pressure at the exit elastic zone is shown in equation (4). Fig. 11 is the diagram of elastic flattening and rolling pressure. 


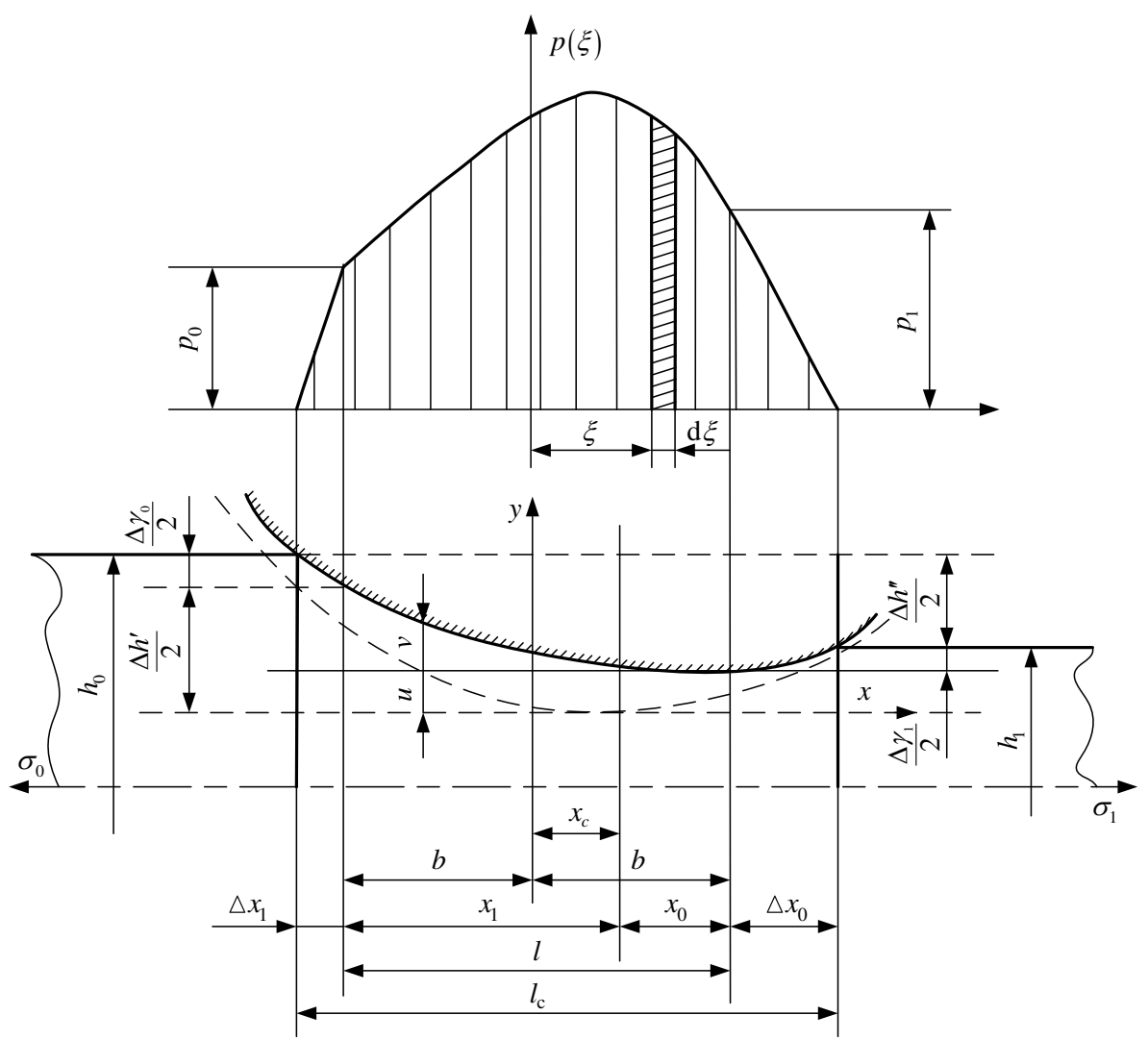

Fig. 11 Diagram of elastic flattening and rolling pressure

$$
p_{x}=p_{1} \frac{B x-\left(1-B \Delta x_{0}\right)\left(e^{B x}-1\right)}{1-\left(1-B \Delta x_{0}\right) e^{B \Delta x_{0}}}
$$

In equation (4), $p_{x}$ is rolling pressure in export elastic zone, $M P a . p_{1}$ is pressure at the beginning of the elastic zone into the plastic zone, $M P a . B$ is constant $B=\frac{2 \mu \nu}{(1-v) h_{1}} \cdot \quad x \quad$ is rolling direction coordinates, $m m . \Delta x_{0}$ is deformation zone length increment, $\mathrm{mm}$.

Studying the lateral distribution of rolling pressure should consider the lateral flow of metal ${ }^{[25 ~ 26]}$. The lateral flow of metal mainly occurs in the plastic deformation zone. When the lateral distribution of rolling pressure is calculated, the longitudinal stress needs to be determined according to the longitudinal friction ${ }^{[27 ~ 29]}$. The lateral distribution of rolling pressure is shown in equation (5).

$$
p(x, y)=\frac{2+\alpha}{\sqrt{1+\alpha+\alpha^{2}+\left(\frac{1+\alpha}{2}\right)^{2}\left(\frac{d \gamma_{x y}}{d \varepsilon_{z}}\right)^{2}}} K-\sigma_{x}
$$

In equation (5), $p(x, y)$ is lateral distribution of rolling pressure, $M P a . \alpha$ is bite angle, $\mathrm{rad} . K$ is pure shear resistance, $M P a . \sigma_{x}$ is $x$ direction stress component, $M P a . \gamma_{x y}$ is shear strain. $\varepsilon_{z}$ is deformation in $z$ direction.

\subsubsection{Effect of work roll bending on rolling pressure distribution along strip width}

The simulation experiment parameters of the influence of work roll bending on the distribution of rolling pressure along the strip width are shown in Table 7. 
Table 7 Simulation experiment parameters of the influence of work roll bending on the distribution of rolling pressure along the strip width

\begin{tabular}{cccccc}
\hline $\begin{array}{c}\text { Test } \\
\text { group }\end{array}$ & $\begin{array}{c}\text { Work roll } \\
\text { bending/kN }\end{array}$ & $\begin{array}{c}\text { Front } \\
\text { tension/MPa }\end{array}$ & $\begin{array}{c}\text { Back } \\
\text { tension/MPa }\end{array}$ & $\begin{array}{c}\text { Rolling } \\
\text { speed/(m/min })\end{array}$ & $\begin{array}{c}\text { Reduction } \\
\text { ratio/\% }\end{array}$ \\
\hline 1 & 0 & 73 & 109 & 870 & 33 \\
2 & 357 & 73 & 109 & 870 & 33 \\
3 & 439 & 73 & 109 & 870 & 33 \\
\hline
\end{tabular}

Fig. 12 is the distribution of rolling pressure along the strip width under different work roll bending forces. When the work roll bending is not put in, the rolling pressure along the strip width is suddenly increased from the middle to the edge, and the peak appears. As the bending force is increased, the sudden increase trend of the rolling pressure along the strip width from the middle to the edge becomes a decrease trend, and the peak disappears.

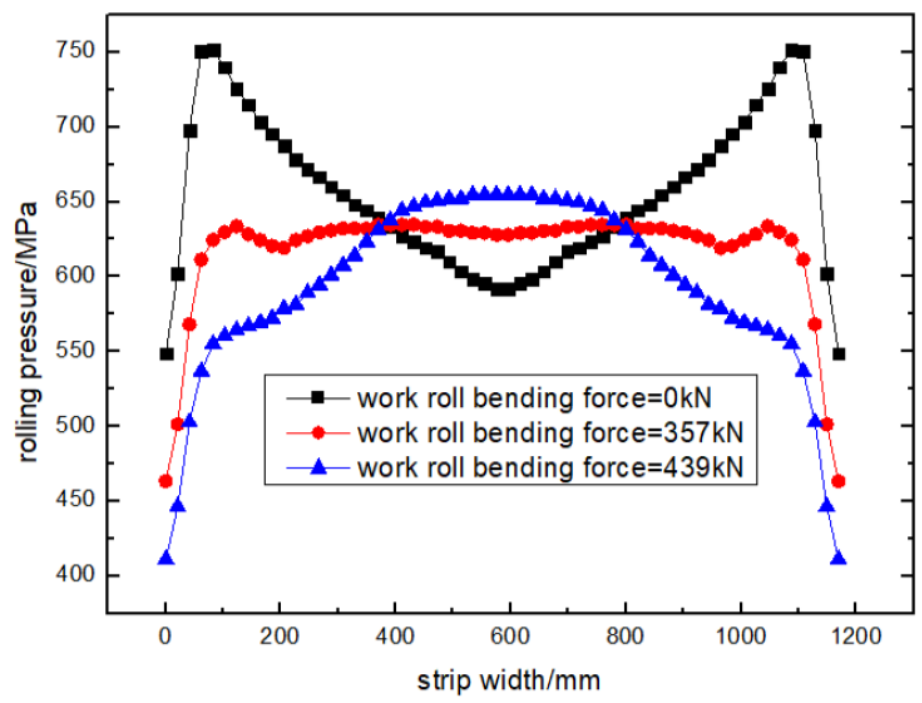

Fig. 12 Distribution of rolling pressure along the strip width under different work roll bending forces

\subsubsection{Effect of intermediate roll shifting on rolling pressure distribution along strip width}

The simulation experiment parameters of the influence of the intermediate roll shifting on the rolling pressure distribution along the strip width are shown in Table 8.

Table 8 Simulation experiment parameters of the influence of the intermediate roll shifting on the rolling pressure distribution along the strip width

\begin{tabular}{cccccc}
\hline $\begin{array}{c}\text { Test } \\
\text { group }\end{array}$ & $\begin{array}{c}\text { Intermediate roll } \\
\text { shifting/mm }\end{array}$ & $\begin{array}{c}\text { Front } \\
\text { tension/MPa }\end{array}$ & $\begin{array}{c}\text { Back } \\
\text { tension/MPa }\end{array}$ & $\begin{array}{c}\text { Rolling } \\
\text { speed/(m/min) }\end{array}$ & $\begin{array}{c}\text { Reduction } \\
\text { ratio/\% }\end{array}$ \\
\hline 1 & 0 & 103 & 139 & 990 & 24 \\
2 & 117 & 103 & 139 & 990 & 24 \\
3 & 193 & 103 & 139 & 990 & 24 \\
\hline
\end{tabular}

Fig. 13 is the distribution of rolling pressure along the strip width under different intermediate roll shifting. With the increase in the amount of intermediate roll shifting, the sudden increase of the rolling pressure along the strip width at the edge is gradually slowing down. The rolling pressure is also reduced along the contact arc, but the distribution trend is basically unchanged. 


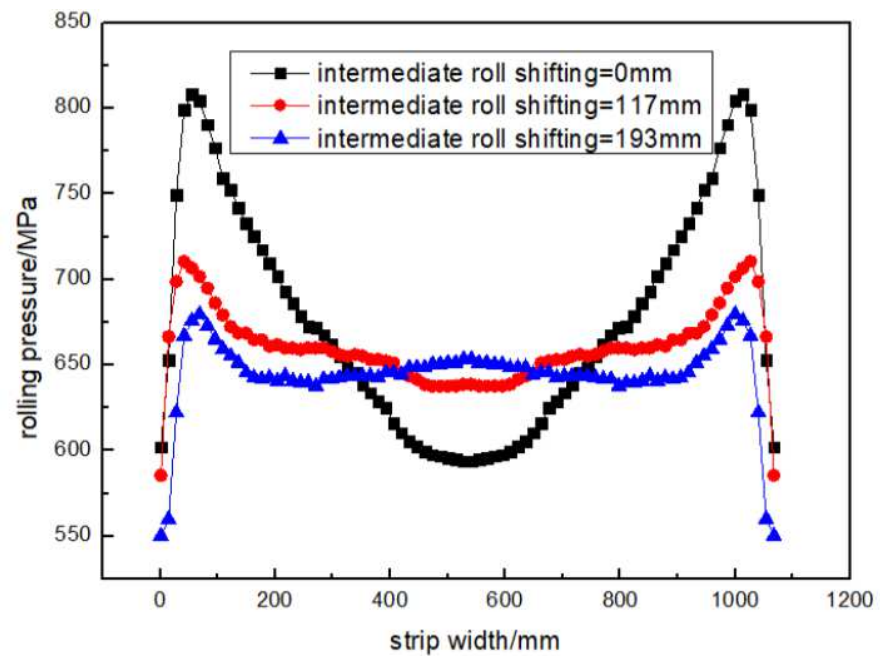

Fig. 13 Distribution of rolling pressure along the strip width under different intermediate roll shifting

\subsubsection{Effect of intermediate roll bending on the distribution of rolling pressure along the strip width}

The simulation experiment parameters of the influence of the intermediate roll bending on the distribution of rolling pressure along the strip width are shown in Table 9.

Table 9 Simulation experiment parameters of the influence of the intermediate roll bending on the distribution of rolling pressure along the strip width

\begin{tabular}{cccccc}
\hline $\begin{array}{c}\text { Test } \\
\text { group }\end{array}$ & $\begin{array}{c}\text { Intermediate roll } \\
\text { bending/kN }\end{array}$ & $\begin{array}{c}\text { Front } \\
\text { tension/MPa }\end{array}$ & $\begin{array}{c}\text { Back } \\
\text { tension/MPa }\end{array}$ & $\begin{array}{c}\text { Rolling } \\
\text { speed } /(\mathrm{m} / \mathrm{min})\end{array}$ & $\begin{array}{c}\text { Reduction } \\
\text { ratio/\% }\end{array}$ \\
\hline 1 & 0 & 73 & 159 & 790 & 34 \\
2 & 317 & 73 & 159 & 790 & 34 \\
3 & 579 & 73 & 159 & 790 & 34 \\
\hline
\end{tabular}

Fig. 14 is the distribution of rolling pressure along the strip width under different intermediate roll bending. Compared with the effect of work roll bending on the rolling pressure, the intermediate roll bending has little effect on it. The trend of rolling pressure distribution along the strip width has basically not changed. And the peak value is only slightly decreased, but it does not disappear.

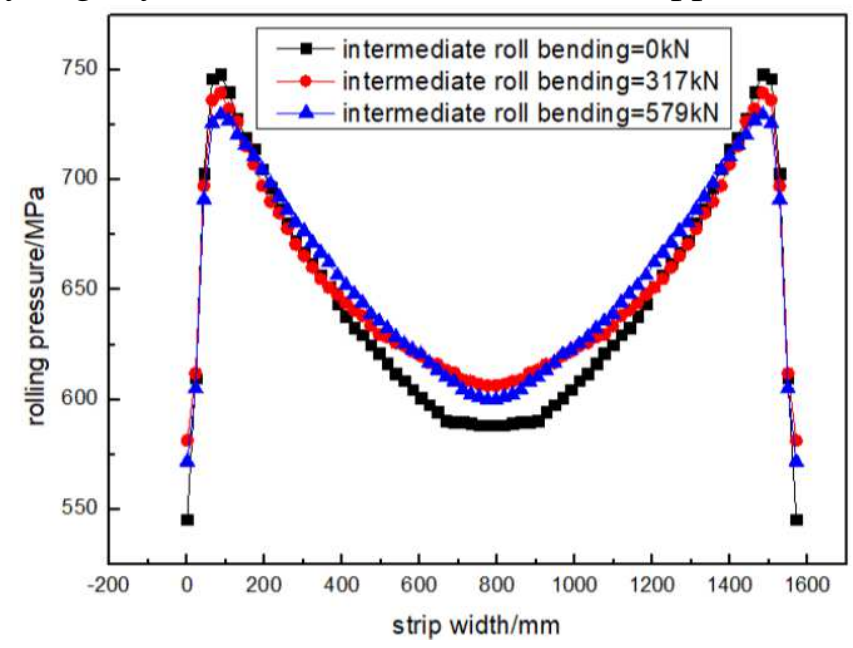

Fig. 14 Distribution of rolling pressure along the strip width under different intermediate roll bending 


\subsection{Analysis of influencing factors of lateral thickness distribution}

\subsubsection{Effect of Work Roll Bending on the lateral thickness distribution of Strip}

Steel

The simulation experiment parameters of the influence of the work roll bending on the lateral thickness distribution of the strip are shown in Table $\mathbf{1 0 .}$

Table 10 Simulation experiment parameters of the influence of the work roll bending on the lateral thickness distribution of the strip

\begin{tabular}{cccccc}
\hline $\begin{array}{c}\text { Test } \\
\text { group }\end{array}$ & $\begin{array}{c}\text { Work roll } \\
\text { bending/t }\end{array}$ & $\begin{array}{c}\text { Front } \\
\text { tension/MPa }\end{array}$ & $\begin{array}{c}\text { Back } \\
\text { tension/MPa }\end{array}$ & $\begin{array}{c}\text { Rolling } \\
\text { speed/(m/min })\end{array}$ & $\begin{array}{c}\text { Reduction } \\
\text { ratio/\% }\end{array}$ \\
\hline 1 & 0 & 83 & 127 & 1090 & 14 \\
2 & 27 & 83 & 127 & 1090 & 14 \\
3 & 51 & 83 & 127 & 1090 & 14 \\
\hline
\end{tabular}

Fig. 15 is the lateral thickness distribution of strip steel for different work roll bending. As the work roll bending force becomes larger, the thickness of the central zone is increased. At the same time, with the increase of the bending force, the thickness of the edge zone is significantly increased except for the thinned area. When the bending force is $51 \mathrm{t}$, the thickness of the edge is greater than the thickness of the center, and the negative convexity appears. Compared with the case without roll bending force, the shape of the strip section has a big change.

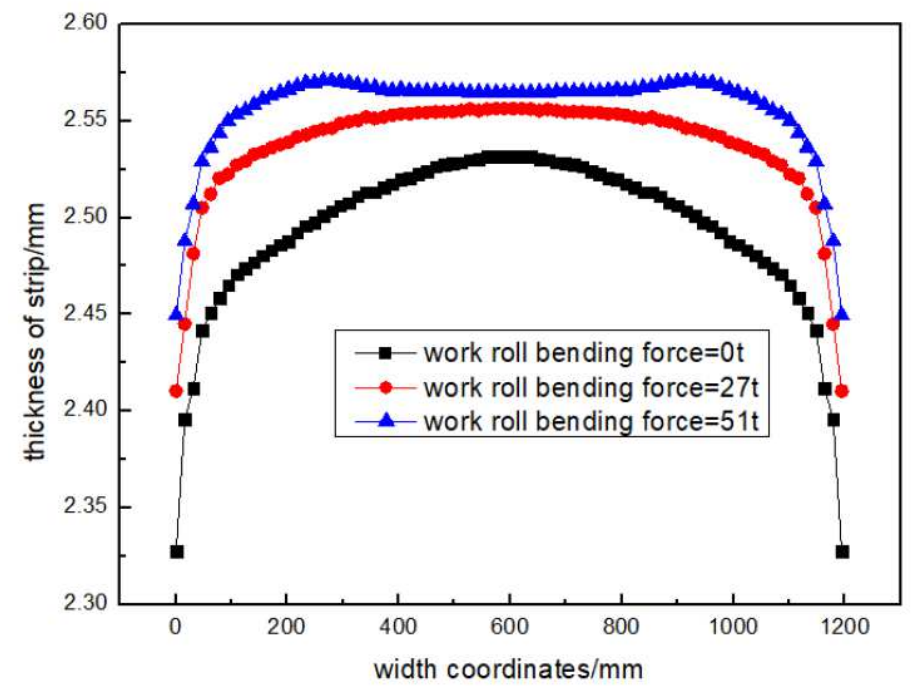

Fig. 15 Lateral thickness distribution of strip steel for different work roll bending

\subsubsection{Effect of intermediate roll bending on the lateral thickness distribution of} strip

The simulation experiment parameters of the influence of the intermediate roll bending on the lateral thickness distribution of the strip are shown in Table $\mathbf{1 1 .}$

Table 11 Simulation experiment parameters of the influence of the intermediate roll bending on the lateral thickness distribution of the strip

\begin{tabular}{cccccc}
\hline $\begin{array}{c}\text { Test } \\
\text { group }\end{array}$ & $\begin{array}{c}\text { Intermediate roll } \\
\text { bending/t }\end{array}$ & $\begin{array}{c}\text { Front } \\
\text { tension/MPa }\end{array}$ & $\begin{array}{c}\text { Back } \\
\text { tension/MPa }\end{array}$ & $\begin{array}{c}\text { Rolling } \\
\text { speed } /(\mathrm{m} / \mathrm{min})\end{array}$ & $\begin{array}{c}\text { Reduction } \\
\text { ratio/\% }\end{array}$ \\
\hline 1 & 0 & 79 & 97 & 760 & 16 \\
2 & 31 & 79 & 97 & 760 & 16 \\
\hline
\end{tabular}




\begin{tabular}{llllll}
\hline 3 & 59 & 79 & 97 & 760 & 16 \\
\hline
\end{tabular}

Fig. 16 is the lateral thickness distribution of strip steel under different intermediate roll bending. The effect of the intermediate roll bending on the shape of the strip section is small. The effect of intermediate roll bending on the thickness distribution curve is not particularly obvious. And its basic shape remains unchanged. As the bending force is increased, the thickness of the strip center is increased.

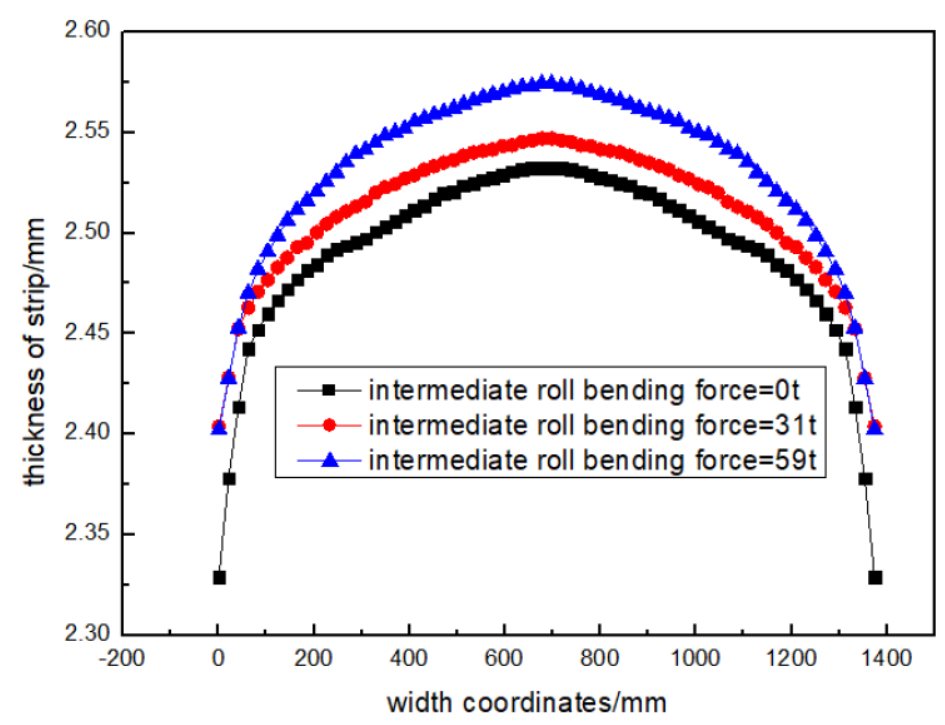

Fig. 16 Lateral thickness distribution of strip steel under different intermediate roll bending

\subsection{Analysis of influencing factors of work roll deflection}

The deflection of the work roll has a great influence on the strip flatness control. During the rolling process, on the one hand, the deflection of the work roll is the uneven contact deformation between the work roll and the intermediate roll and between the work roll and the strip. On the other hand, because the contact length between the roll is greater than the width of the strip, the harmful contact portion makes the work roll subjected to cantilever bending. The deflection caused by the total bending deformation of the work roll is shown in equation (6). The deflection caused by the total shear deformation of the work roll is shown in equation (7).

$$
g_{w}^{B}(i, j)=\left.\frac{\partial U_{b}}{\partial \bar{p}}\right|_{\bar{p}=0}=\frac{l_{w}^{3}}{6 E_{w} I_{w}}\left\{\left(\frac{x_{j}}{l_{w}}\right)^{2}\left(\frac{3 x_{i}}{l_{w}}-\frac{x_{j}}{l_{w}}\right)\right\}
$$

In equation (6), $g_{w}^{B}(i, j)$ is the deflection of the $i$ unit caused by the total bending deformation when unit force is applied in unit $j, \mathrm{~mm} / \mathrm{kN} . U_{b}$ is total bending deformation energy, $k N \times m m . \bar{p}$ is the virtual force acting on the $i$ unit, $k N . l_{w}$ is half of work roll length, $m m . E_{w}$ is Young's modulus of work roll, $\mathrm{kN} / \mathrm{mm}^{2} . I_{w}$ is modulus of bending section of work roll, $\mathrm{mm}^{4} . x_{i}$ is $i$ unit coordinates, $m m . x_{j}$ is $j$ unit coordinates, $m m$.

$$
g_{w}^{s}(i, j)=\left.\frac{\partial U_{s}}{\partial \bar{p}}\right|_{\bar{p}=0}=\frac{\left(1+v_{w}\right) D_{w}^{2}}{6 E_{w} I_{w}} x_{j}
$$

In equation (7), $g_{w}^{s}(i, j)$ is the deflection of the $i$ unit caused by the total shear deformation when unit force is applied in unit $j, \mathrm{~mm} / \mathrm{kN} . v_{w}$ work roll Poisson's 
ratio. $D_{w}$ is work roll diameter, $m m . U_{s}$ is total shear deformation energy, $k N \times m m$.

\subsubsection{Effect of work roll diameter on work roll deflection}

The simulation experiment parameters of the influence of work roll diameter on work roll deflection are shown in Table 12.

Table 12 Simulation experiment parameters of the influence of work roll diameter on work roll

\begin{tabular}{cccccc}
\multicolumn{7}{c}{$\begin{array}{c}\text { deflection } \\
\text { group }\end{array}$} & $\begin{array}{c}\text { Work roll } \\
\text { diameter/mm }\end{array}$ & $\begin{array}{c}\text { Front } \\
\text { tension/MPa }\end{array}$ & $\begin{array}{c}\text { Back } \\
\text { tension/MPa }\end{array}$ & $\begin{array}{c}\text { Rolling } \\
\text { speed/(m/min })\end{array}$ & $\begin{array}{c}\text { Reduction } \\
\text { ratio/\% }\end{array}$ \\
\hline 1 & 530 & 113 & 147 & 960 & 13 \\
2 & 550 & 113 & 147 & 960 & 13 \\
3 & 610 & 113 & 147 & 960 & 13 \\
\hline
\end{tabular}

Fig. 17 is the work roll deflection distribution of different work roll diameters. As the work roll diameter is decreased, the work roll deflection becomes larger within the width of the strip. The deflection distribution of the work roll in the middle is denser at different diameters. The deflection distribution of the work roll at the edge is more dispersed at different diameters. The effect of the work roll diameter on the deflection distribution of the work roll in the middle is weaker than the effect of the work roll diameter on the deflection distribution of the work roll at the edge.

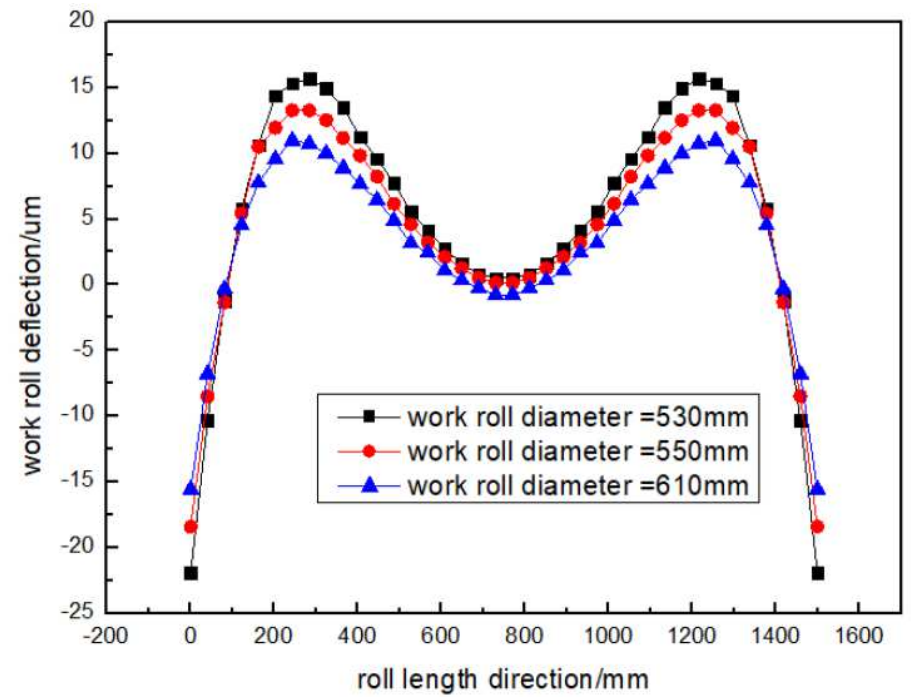

Fig. 17 Work roll deflection distribution of different work roll diameters

\subsubsection{Effect of strip width on work roll deflection}

The simulation experiment parameters of the influence of the strip width on the work roll deflection are shown in Table 13.

Table 13 The simulation experiment parameters of the influence of the strip width on the work roll deflection

\begin{tabular}{cccccc}
\hline $\begin{array}{c}\text { Test } \\
\text { group }\end{array}$ & $\begin{array}{c}\text { Strip } \\
\text { width/mm }\end{array}$ & $\begin{array}{c}\text { Front } \\
\text { tension/MPa }\end{array}$ & $\begin{array}{c}\text { Back } \\
\text { tension/MPa }\end{array}$ & $\begin{array}{c}\text { Rolling } \\
\text { speed/(m/min })\end{array}$ & $\begin{array}{c}\text { Reduction } \\
\text { ratio/\% }\end{array}$ \\
\hline 1 & 910 & 116 & 159 & 1200 & 37 \\
2 & 1130 & 116 & 159 & 1200 & 37 \\
3 & 1350 & 116 & 159 & 1200 & 37 \\
4 & 1570 & 116 & 159 & 1200 & 37 \\
\hline
\end{tabular}


Fig. 18 is the deflection distribution of work roll with different strip widths. As the strip width is increased, the deflection value of the work roll within the width of the strip becomes smaller. When the strip width is $910 \mathrm{~mm}$ and $1130 \mathrm{~mm}$, the work roll deflection has a peak at the side, and as the strip width is increased, the peak value is decreased. When the strip width is $1350 \mathrm{~mm}$ and $1570 \mathrm{~mm}$, the work roll deflection peak disappears at the edge and the curve becomes smooth. When the strip width is small, the work roll deflection has a peak at the edge. When the strip width is increased to a certain level, the deflection distribution curve of the work roll is gradually smoothed.

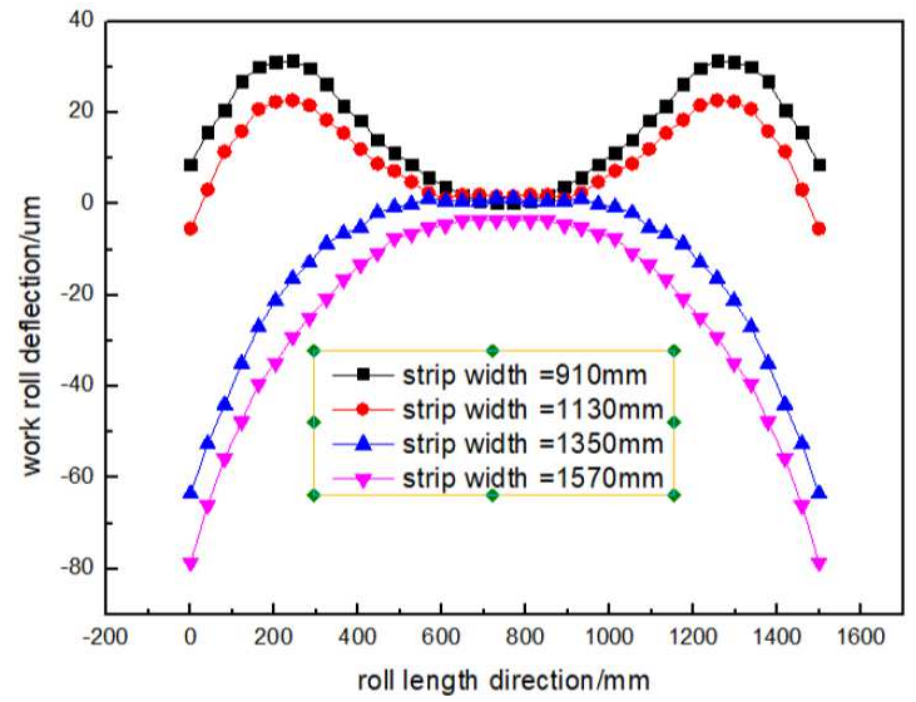

Fig. 18 The deflection distribution of work roll with different strip widths

\subsubsection{Effect of rolling force on work roll deflection}

The simulation experiment parameters of the influence of rolling force on work roll deflection are shown in Table 14.

Table 14 Simulation experiment parameters of the influence of rolling force on work roll deflection

\begin{tabular}{cccccc}
\hline Test group & $\begin{array}{c}\text { Rolling force } \\
\mathrm{kN} / \mathrm{mm}\end{array}$ & $\begin{array}{c}\text { Front } \\
\text { tension/MPa }\end{array}$ & $\begin{array}{c}\text { Back } \\
\text { tension/MPa }\end{array}$ & $\begin{array}{c}\text { Rolling } \\
\text { speed/(m/min })\end{array}$ & $\begin{array}{c}\text { Reduction } \\
\text { ratio/\% }\end{array}$ \\
\hline 1 & 9 & 106 & 139 & 1100 & 27 \\
2 & 11 & 106 & 139 & 1100 & 27 \\
3 & 15 & 106 & 139 & 1100 & 27 \\
\hline
\end{tabular}

Fig. 19 is the deflection distribution of work roll with different rolling force. When the rolling force is increased, the deflection of the roll system is increased within the width of the strip. As the rolling force is increased, the effect of work roll deflection on the strip edge drop is increased. As the unit rolling force is decreased from $15 \mathrm{kN} / \mathrm{mm}$ to $9 \mathrm{kN} / \mathrm{mm}$, the work roll deflection value is gradually decreased to zero. 


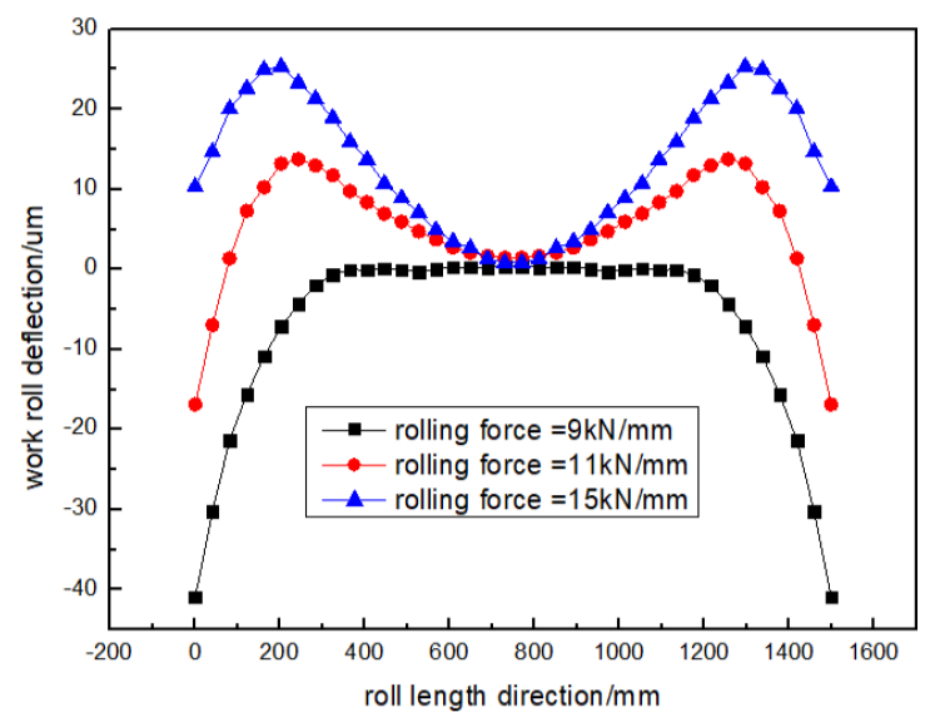

Fig. 19 Deflection distribution of work roll with different rolling force

\section{Conclusion}

Through finite element analysis software ANSYS/LS-DYNA, a three-dimensional simulation model of the rolling process is established. The accuracy of the model is verified by comparing and analyzing the measured and simulated values of the lateral thickness distribution. The results show that the analysis of the strip rolling process based on the three-dimensional finite element model of the rolling mill has high reliability.

The dynamic simulation of the rolling process is carried on. The main analysis content is as follows.

(1) The stress distribution of cold rolling strip at different reductions is obtained. With the increase of the reduction, the area of the large equivalent stress of the strip is increased, and the area of the second large equivalent stress of the strip is decreased.

(2) The distributions curve of control efficiency coefficients at different strip widths, rolling forces, work roll bending forces and intermediate roll bending forces is obtained. As the width of the strip is increased, the control capability of the roll bending flatness control technology is increased. After the rolling force exceeds a certain value, the control efficiency coefficient of the roll bending is basically unchanged.

(3) The rolling pressures along the width direction of different work roll bending, intermediate roll shifting and intermediate roll bending are obtained. As the bending force of the work roll is increased, the sudden increase trend of the rolling pressure in the edge zone from the middle to both sides becomes a decrease trend. As the amount of intermediate roll shifting is increased, the sudden increase trend of rolling pressure in the edge zone is slowing. With the increase of the intermediate roll bending, the rolling pressure distribution trend has not changed.

The lateral thickness distribution of different work roll bending and intermediate roll bending is obtained. As the work roll bending force is increased, the thickness of the center strip is increased. As the bending force of the intermediate roll is increased, the thickness distribution curve changes are not particularly obvious. 
The work roll deflection distribution for different work roll diameters, strip widths and rolling forces is obtained. As the work roll diameter is decreased, the work roll deflection becomes larger within the width of the strip. As the strip width is increased, the work roll deflection becomes smaller within the strip width. As the rolling force is increased, the work roll deflection becomes larger within the width of the strip.

\section{Acknowledgments}

This study is financially supported by National Key R\&D Program of China (2017YFB0304100), National Natural Science Foundation of China (No.: 51804133, 61703200), the Natural Science Foundation of Jiangsu Provincial of China (No.: BK20180977, BK20181024), and the Foundation of Nanjing Institute of Technology (No.: YKJ201867, YKJ2019112).

\section{References}

[1] X. H. Liu, X. Shi, S. Q. Li, J. Y. XU, G. D. WANG, Journal of Iron and Steel Research International, 14: 22-26 (2007).

[2] L. hu, K. zhi, Z. Y. Jiang, J. W. Zhao, F. Li, D. B. Wei, J. Z. Xu, X. M. Zhang, X. M. Zhao, The International Journal of Advanced Manufacturing Technology, 74: 1733-1745 (2014).

[3] Q. L. Wang, J. Sun, Y. M. Liu, P. F. Wang, D. H. Zhang, The International Journal of Advanced Manufacturing Technology, 92: 1371-1389 (2017).

[4] J. Sun, Y. M. Liu, Q. L. Wang, Y. K. Hu, D. H. Zhang, The International Journal of Advanced Manufacturing Technology, 97: 1847-1859 (2018).

[5] H. B. Li, Z. W. Zhao, J. Zhang, N. Kong, F. He, The International Journal of Advanced Manufacturing Technology, 100: 2387-2399 (2019).

[6] H. Park, S. Hwang, Steel research international, 88 (12) (2017).

[7] Q. L. Wang, X. Li, Y. J. Hu, J. Sun, D. H. Zhang, Steel research international, 89 (5) (2018).

[8] X. Lu, J. Sun, G. T. Li, Q. L. Wang, D. H. Zhang, Journal of Materials Processing Technology, 272: 47-57 (2019).

[9] Q. L. Wang, J. Sun, X. Li, Y. M. Liu, P. F. Wang, D. H. Zhang, Journal of Manufacturing Processes, 34: 637-649 (2018).

[10] X. C. Wang, Q. Yang, H. N. He, Y. Z. Sun, Y. Liu, The International Journal of Advanced Manufacturing Technology, 107: 2497-2511 (2020).

[11] S. Kapil, P. Eberhard, K. D. Santosha, Journal of Manufacturing Science and Engineering, 138 (4) (2016).

[12] M. Mosayebi, F. Zarrinkolah, K. Farmanesh, The International Journal of Advanced Manufacturing Technology, 91: 4359-4369 (2017).

[13] C. H. Wu, L. C Zhang, P. L. Qu, International Journal of Mechanical Sciences, 142-143: 468-479 (2018).

[14] H. N. Bu, Z. W. Yan, D. H. Zhang, S. Z. Chen, Scientia Iranica 23: 2663-2672 (2016).

[15] E. J. M. Geddes, I. Postlethwaite, IEEE Transactions on Control Systems Technology, 6 
(2): 257-269 (1998).

[16] J. A. Polyblank, J. M. Allwood, S. R. Duncan, Journal of Materials Processing Technology, 214 (11): 2333-2348 (2014).

[17] M. Jelali, Journal of Process Control, 17 (10): 805-816 (2007).

[18] P. F. Wang, D. M. Qiao, D. H. Zhang, J. Sun, H. M. Liu, Ironmaking \& Steelmaking, 43 (6): 426-433 (2016).

[19] F. Zhang, A. Malik, Journal of Manufacturing Science and Engineering, 140 (1):011008-1-011008-15 (2018).

[20] Z. H. Wang, D. Y. Gong, X. Li, G. T. Li, D. H. Zhang, The International Journal of Advanced Manufacturing Technology, 93: 3325-3338 (2017).

[21] M. Rout, S. K. Pal, S. B. Singh, Journal of Manufacturing Processes, 24: 283-292 (2016).

[22] J. G. Cao, X. T. Chai, Y. L. Li, N. Kong, S. H. Jia, W. Zeng, Journal of Materials Processing Technology, 252: 432-439 (2018).

[23] Y. Zhang, Q. Yang, X. C. Wang, X. Z. Du, X. Zheng, L. S. Wang, Key Engineering Materials, 443: 21-26 (2010).

[24] B. Moazeni, M. Salimi, The International Journal of Advanced Manufacturing Technology, 77: 1315-1331 (2015).

[25] K. Yasuda, K. Narita, K. Kobayashi, I. Maeno, ISIJ INTERNATIONAL, 31: 594-598 (1991).

[26] Q. L. Wang, J. Sun, Y. M. Liu, P. F. Wang, D. H. Zhang, The International Journal of Advanced Manufacturing Technology, 92: 1371-1389 (2017).

[27] S. H. Lee, G. H. Song, S. J. Lee, B. M. Kim, Journal of Mechanical Science and Technology, 25: 2101-2109 (2011).

[28] S. J. Yoon, T. J. Shin, J. S. Lee, S. M. Hwang, Journal of Manufacturing Science and Engineering, 139: 091003-1-091003-10 (2017).

[29] P. F. Wang, D. H. Zhang, X. Li, W. X. Zhang, STEEL RESEARCH INTERNATIONAL, 82: 379-387 (2011). 

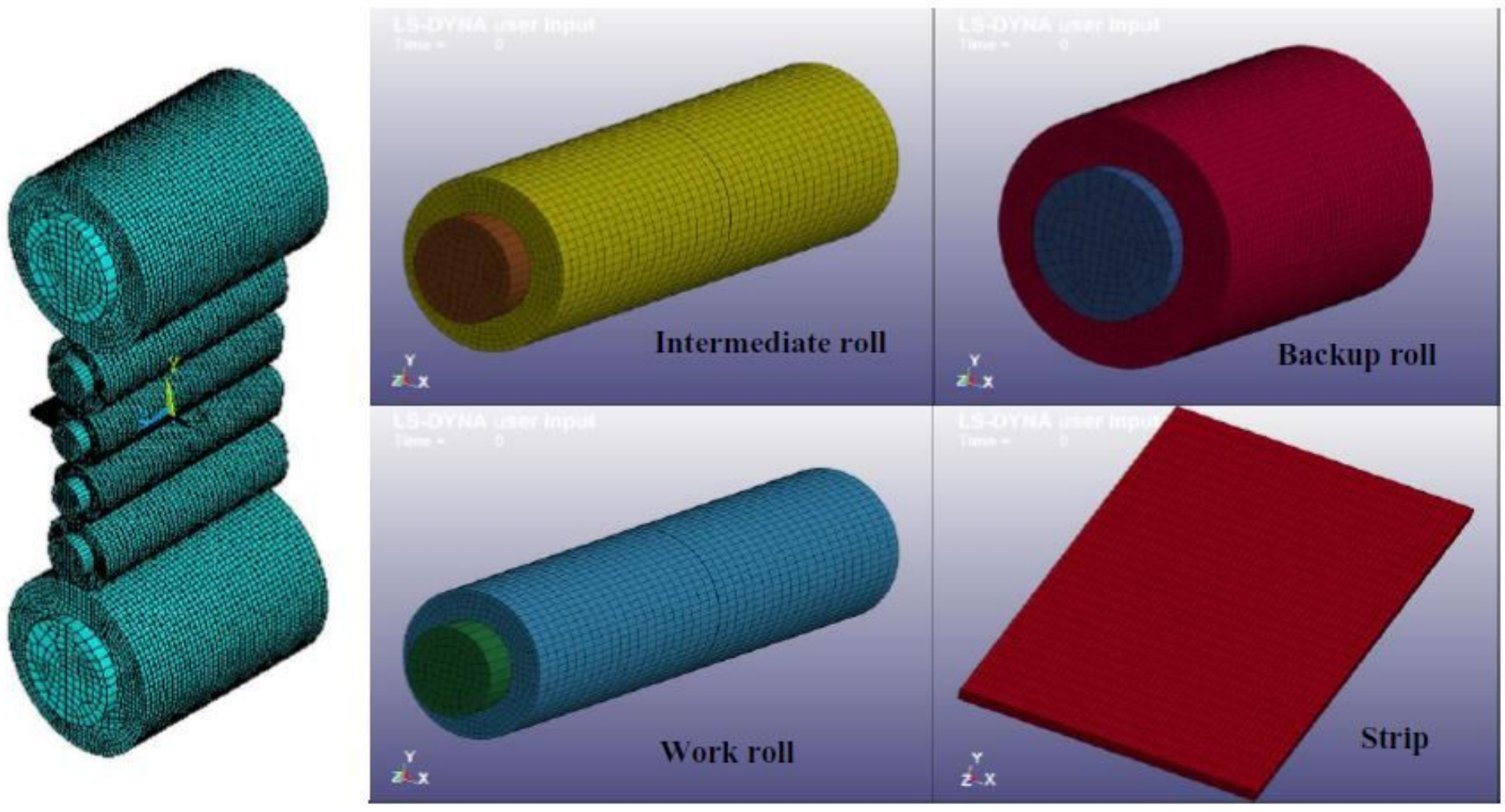

Figure 1

Three-dimensional finite element model

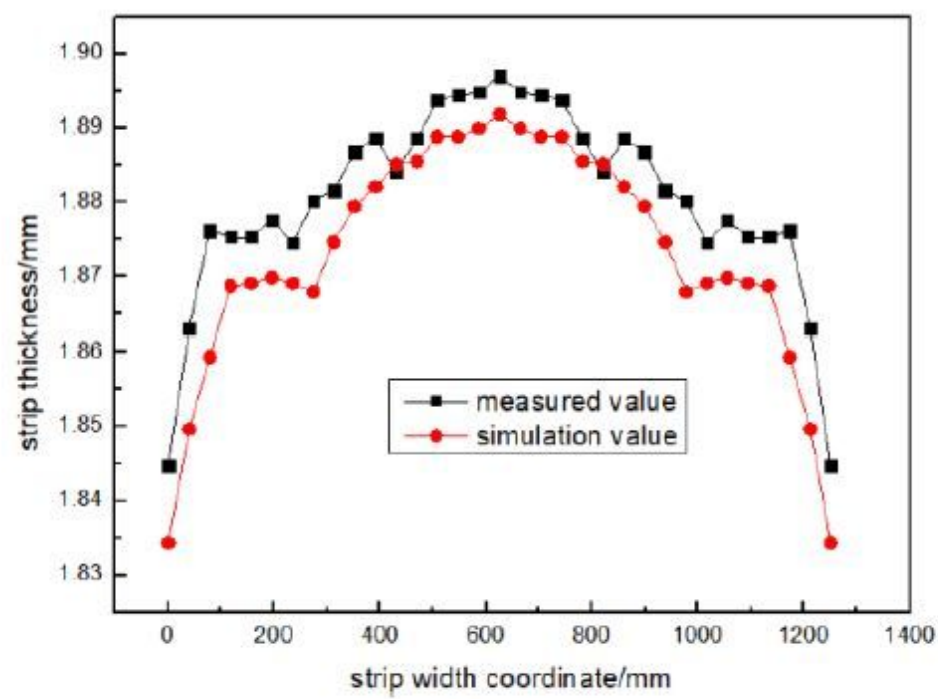

(a) First group

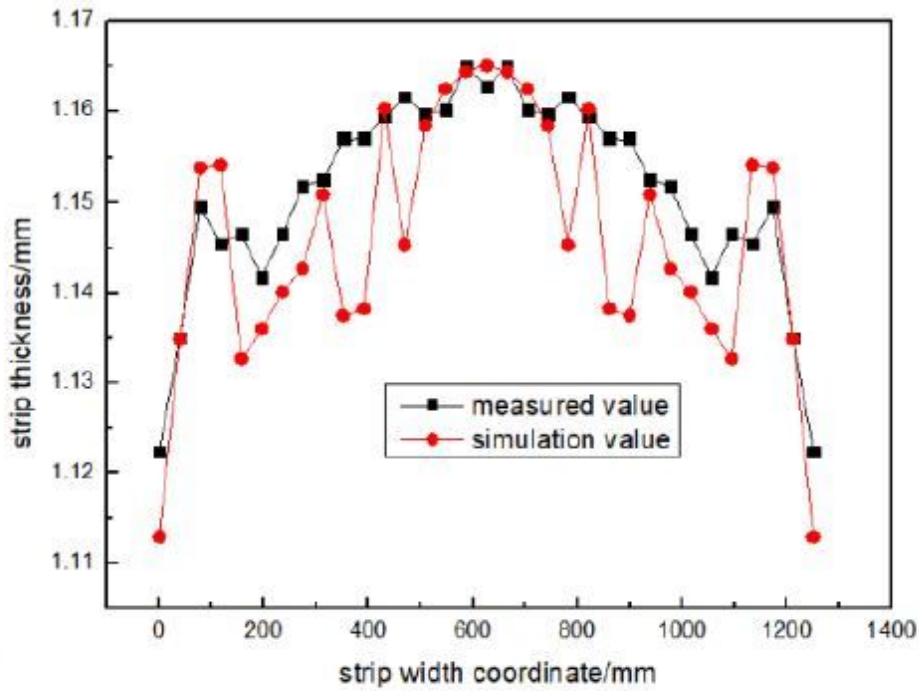

(b) Second group

Figure 2

Distribution diagram of finite element simulation value and actual measured value of lateral thickness distribution of exit strip 


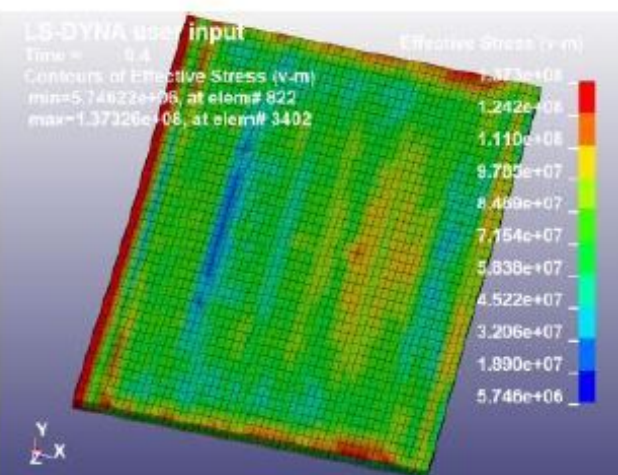

(a) Reduction 0.00705

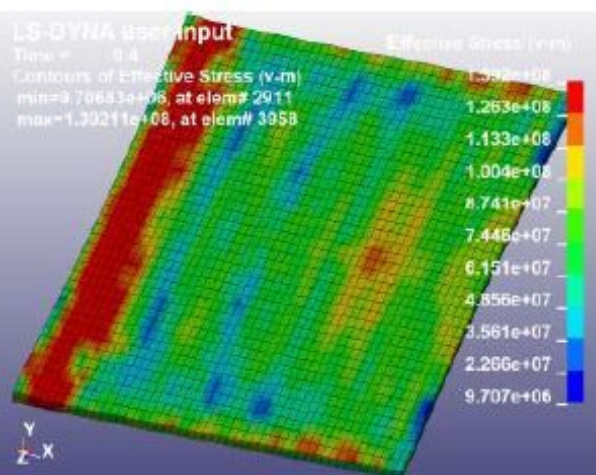

(b) Reduction 0.0105

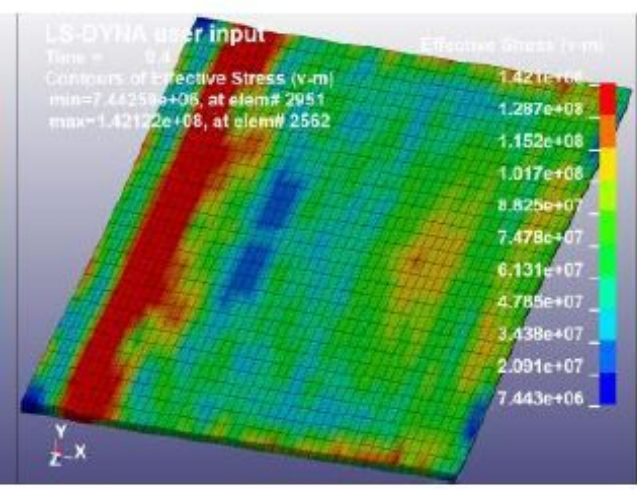

(c) Reduction 0.01405

\section{Figure 3}

Distribution diagram of the equivalent stress of the strip after rolling at different reductions

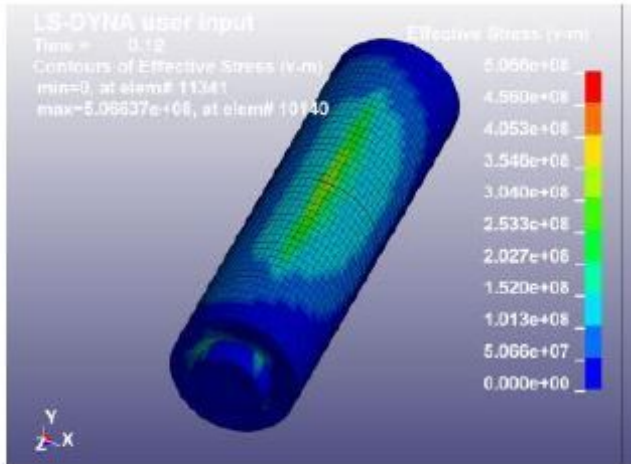

(a) Reduction 0.00705

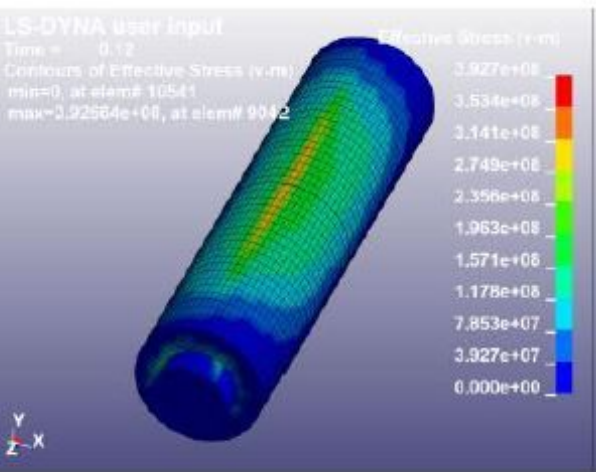

(b) Reduction 0.0105

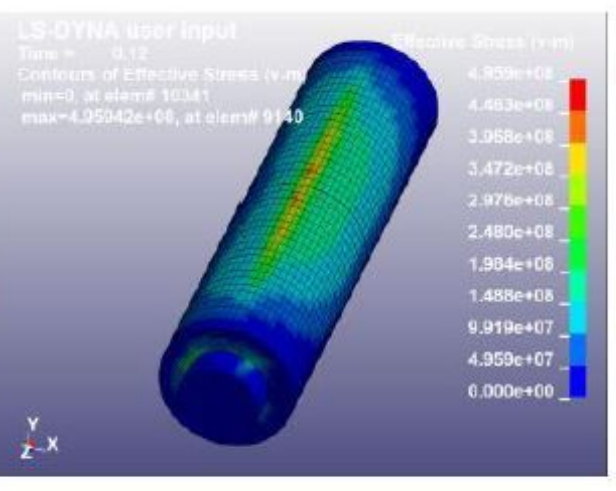

(c) Reduction 0.01405

\section{Figure 4}

The distribution diagram of the equivalent stress of the work roll after rolling at different reductions

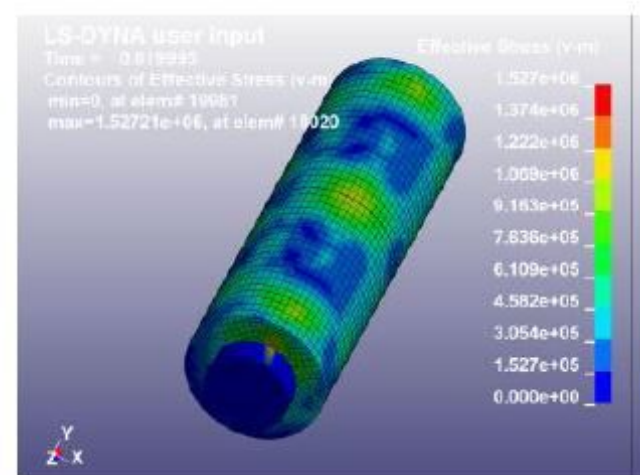

(a) Reduction 0.00705

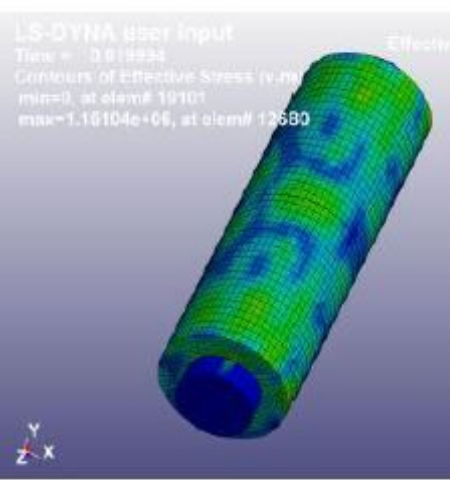

(b) Reduction 0.0105

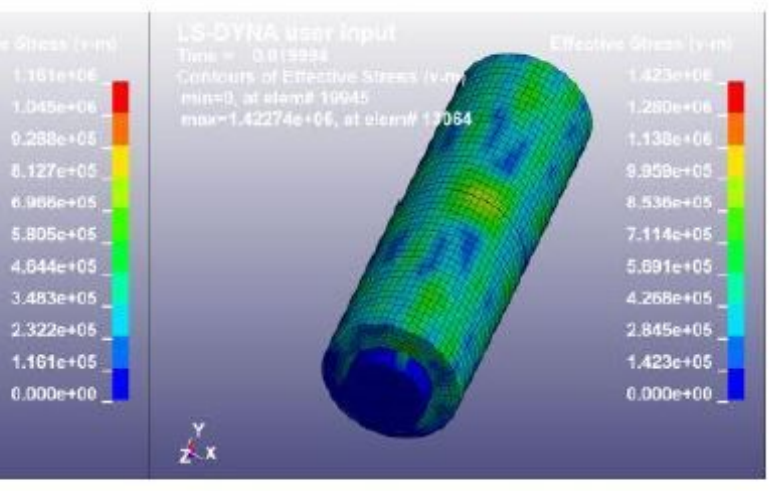

(c) Reduction 0.01405

\section{Figure 5}

Distribution of the equivalent stress of the intermediate roll after rolling at different reductions 


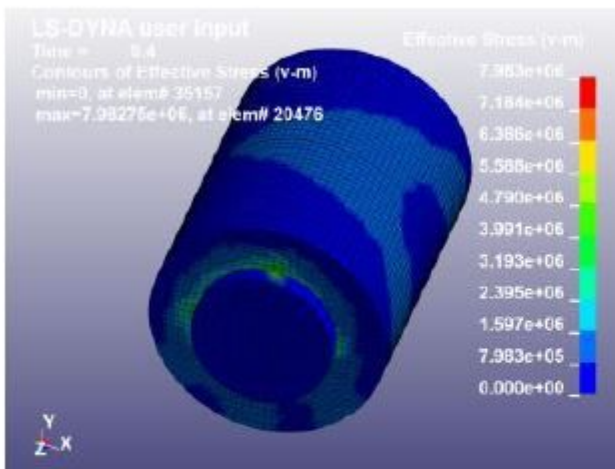

(a) Reduction 0.00705

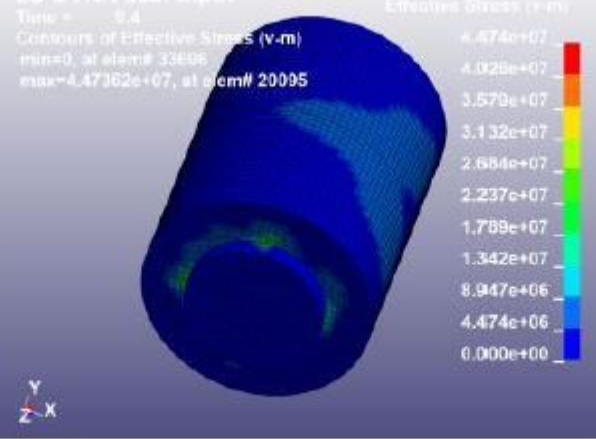

(b) Reduction 0.0105

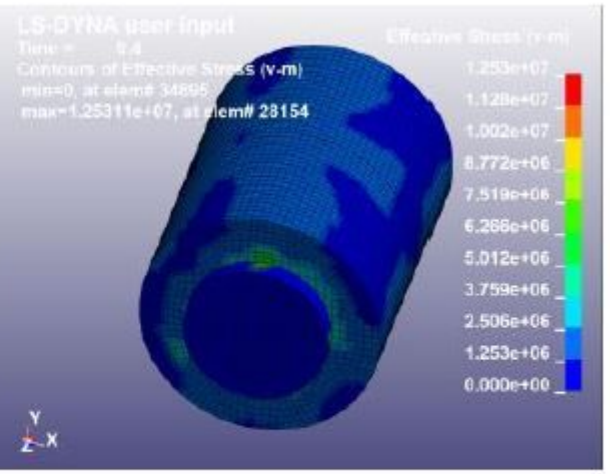

(c) Reduction 0.01405

Figure 6

Distribution of the equivalent stress of the backup roll after rolling at different reductions
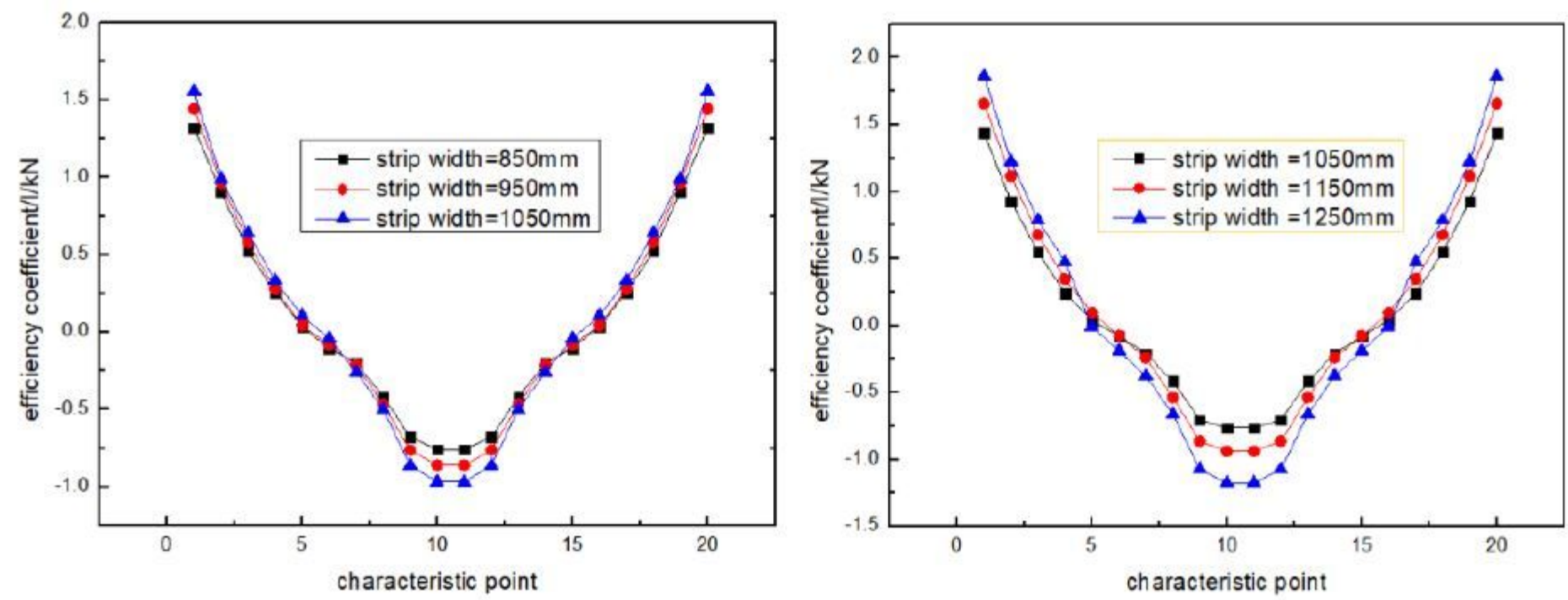

Figure 7

Curve distribution diagram of work roll bending efficiency coefficient at different strip widths 

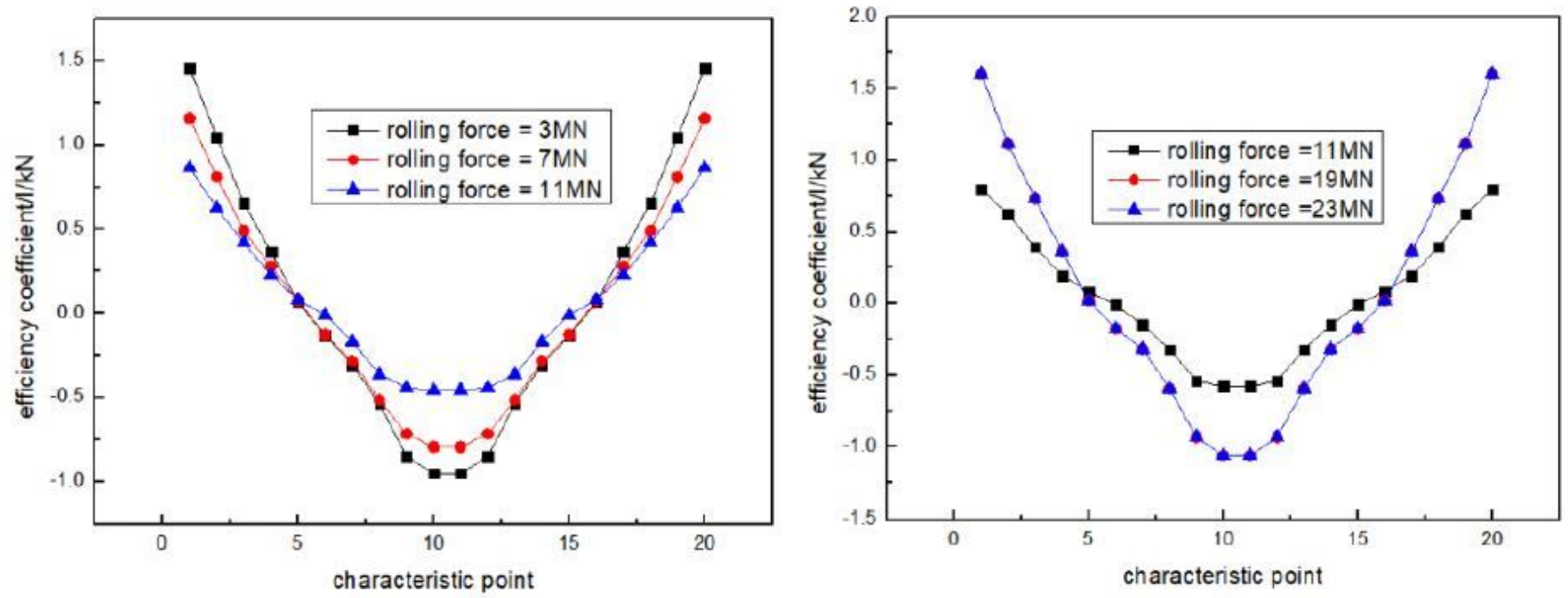

Figure 8

Curve distribution diagram of work roll bending efficiency coefficient at different rolling forces

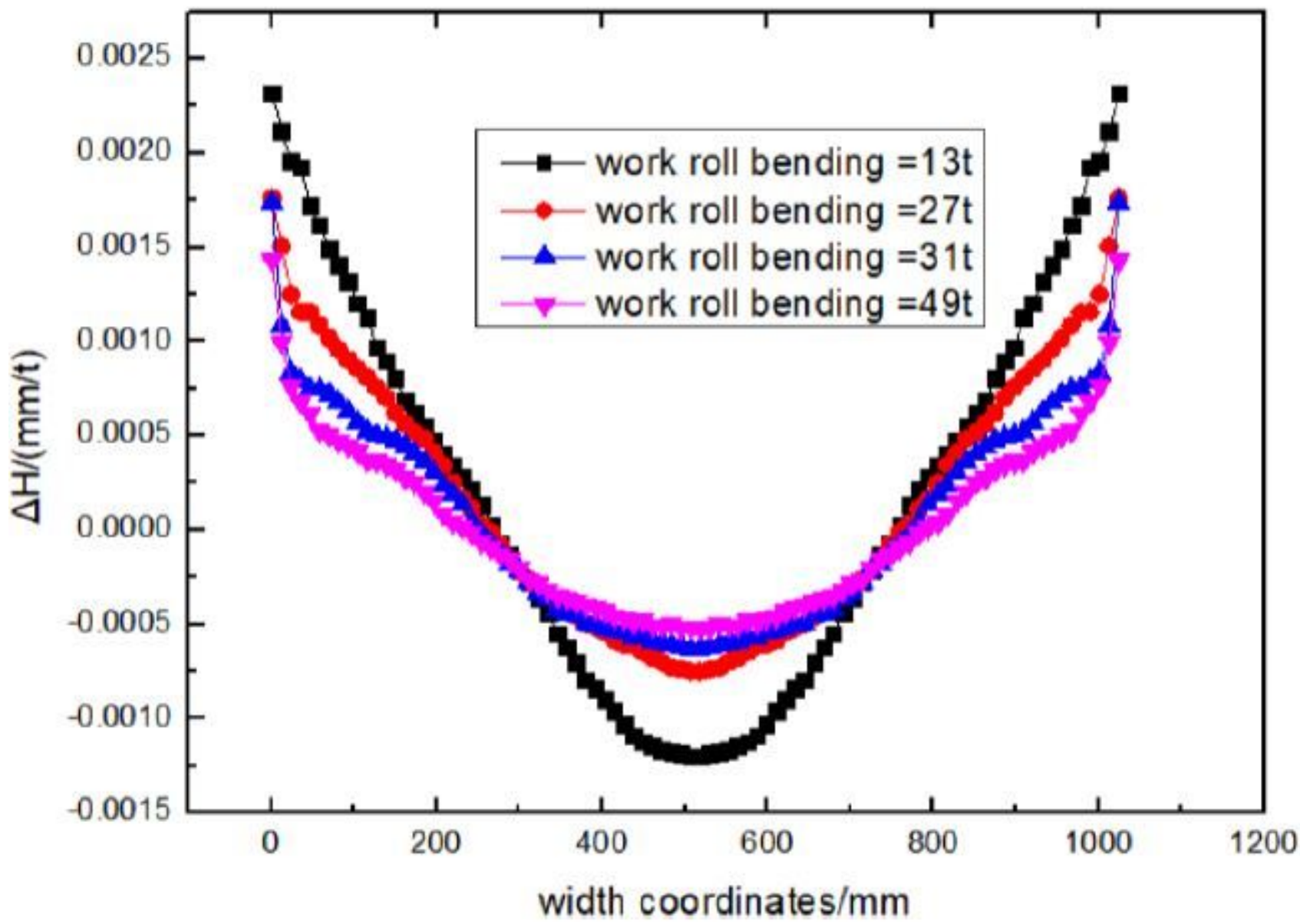

Figure 9

curve distribution of the efficiency coefficient under different bending force 


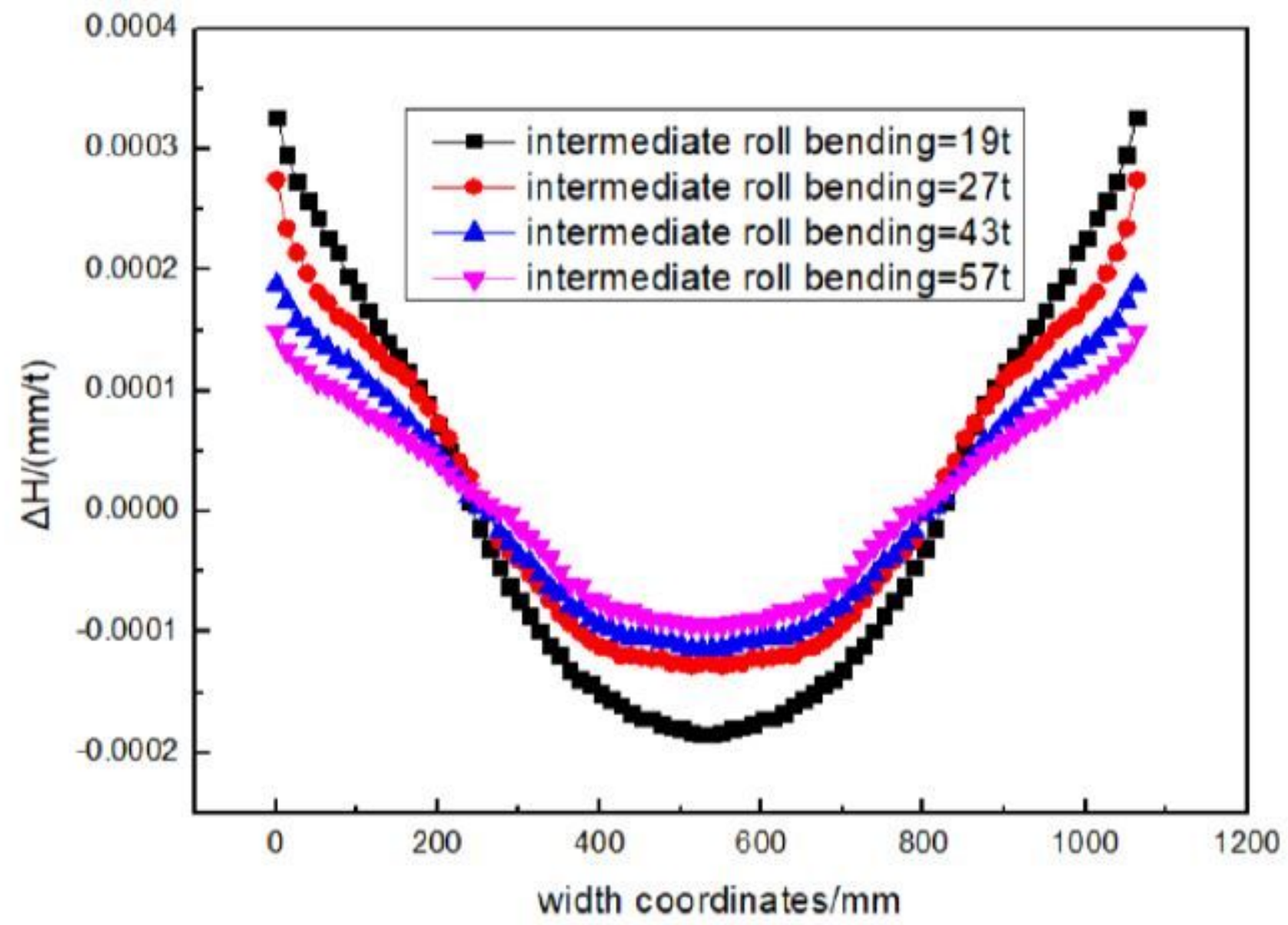

Figure 10

curve distribution of the control efficiency coefficient under different rollingbending force 


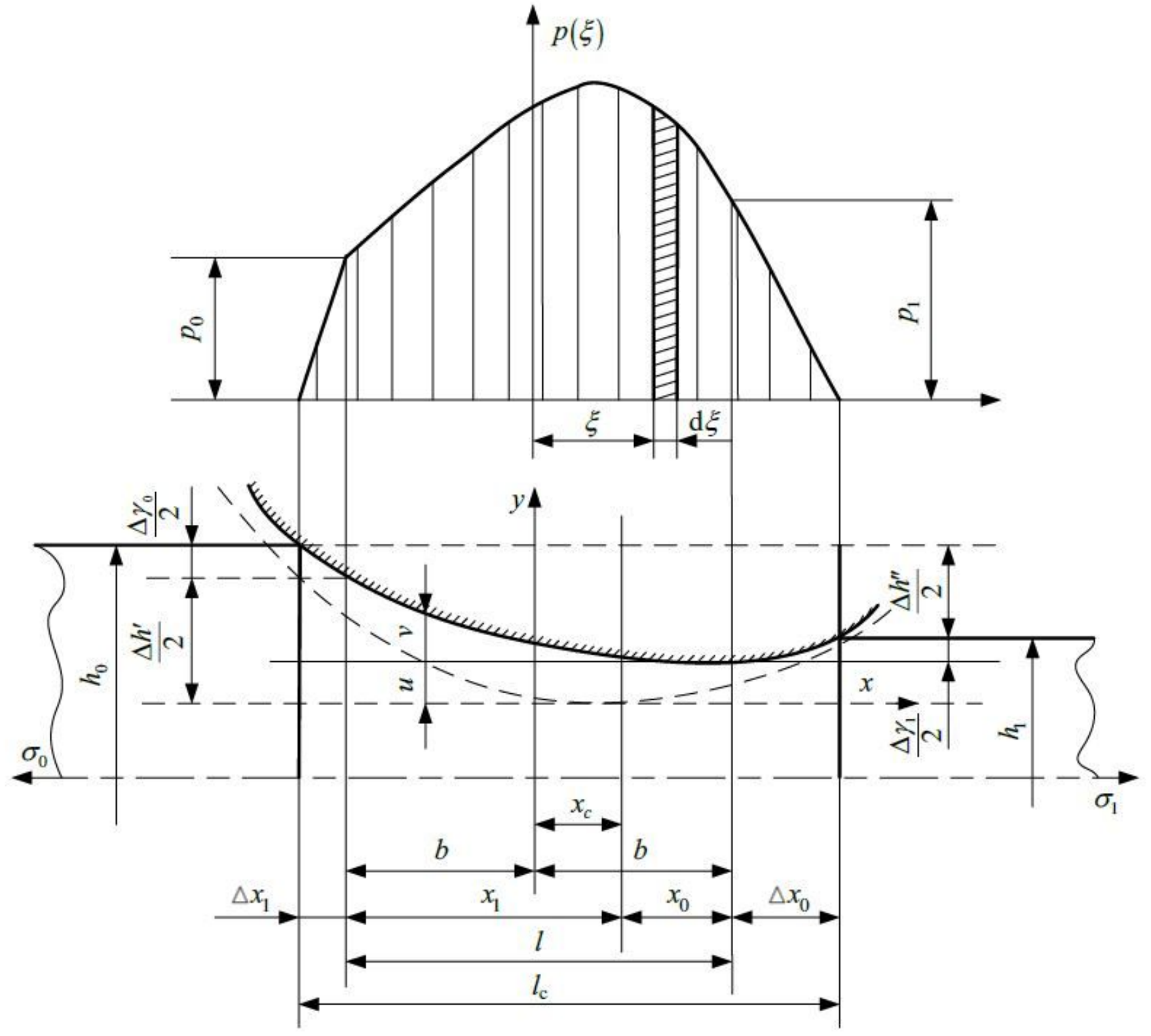

Figure 11

Diagram of elastic flattening and rolling pressure 


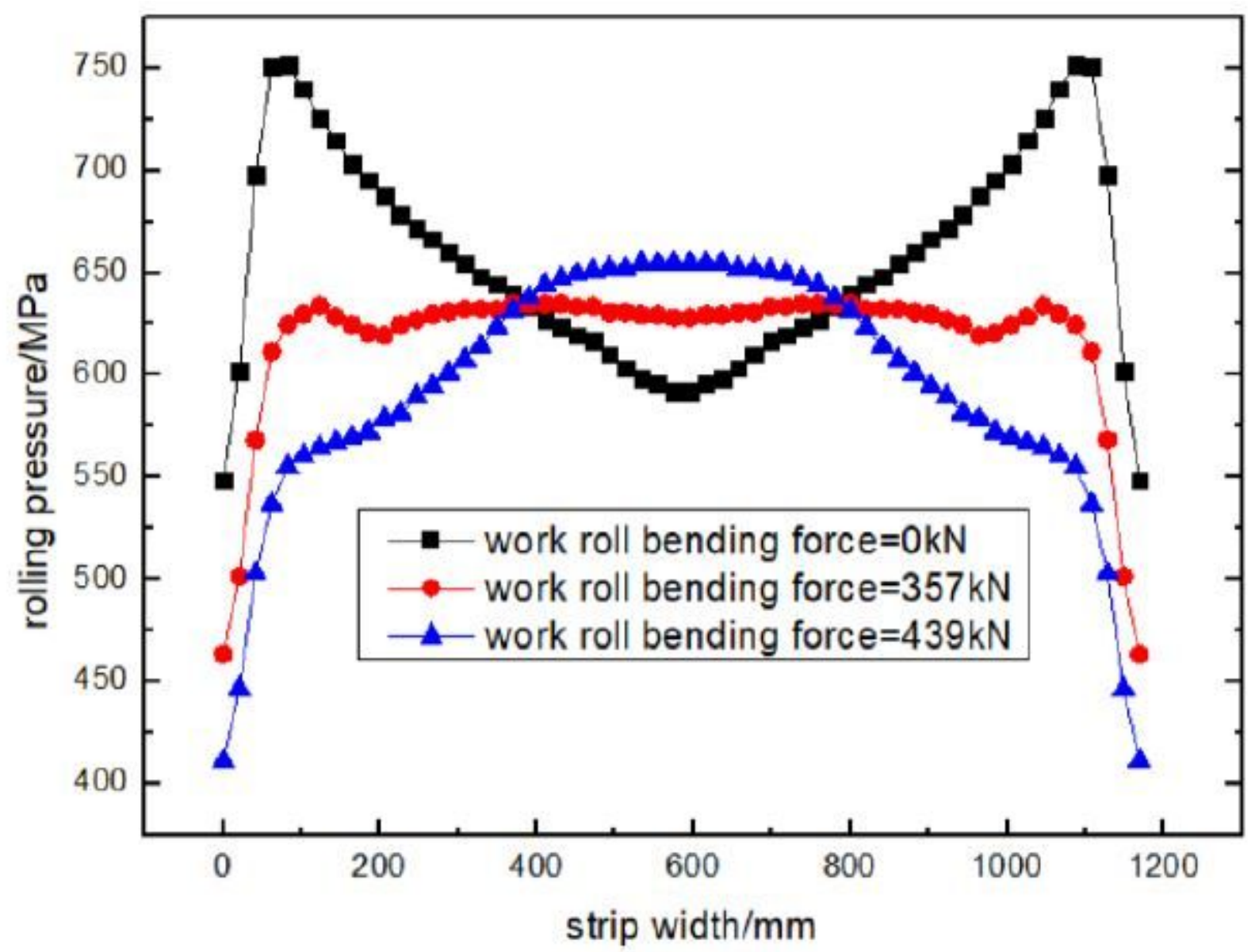

Figure 12

Distribution of rolling pressure along the strip width under different work roll bending forces 


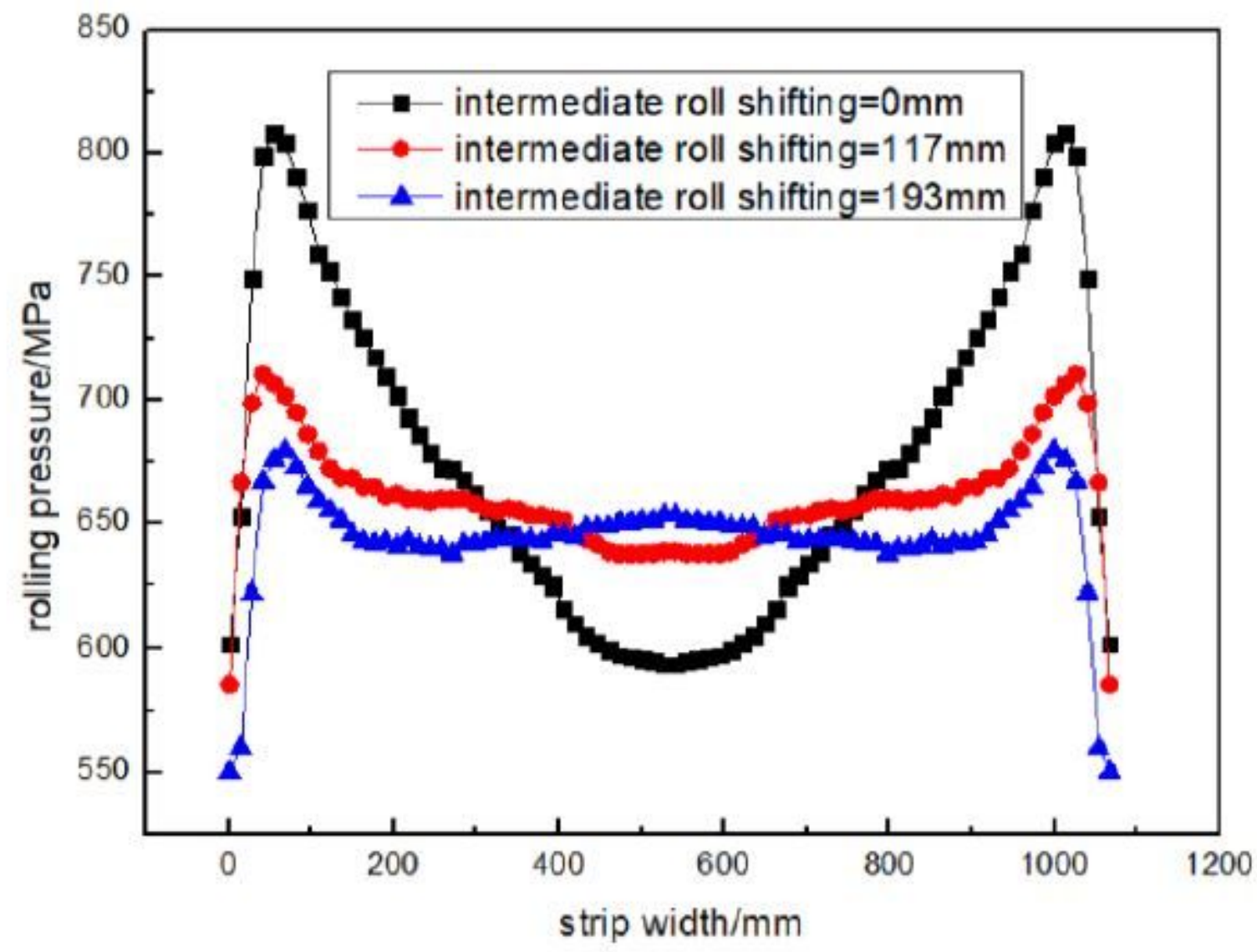

Figure 13

Distribution of rolling pressure along the strip width under different intermediate roll shifting 


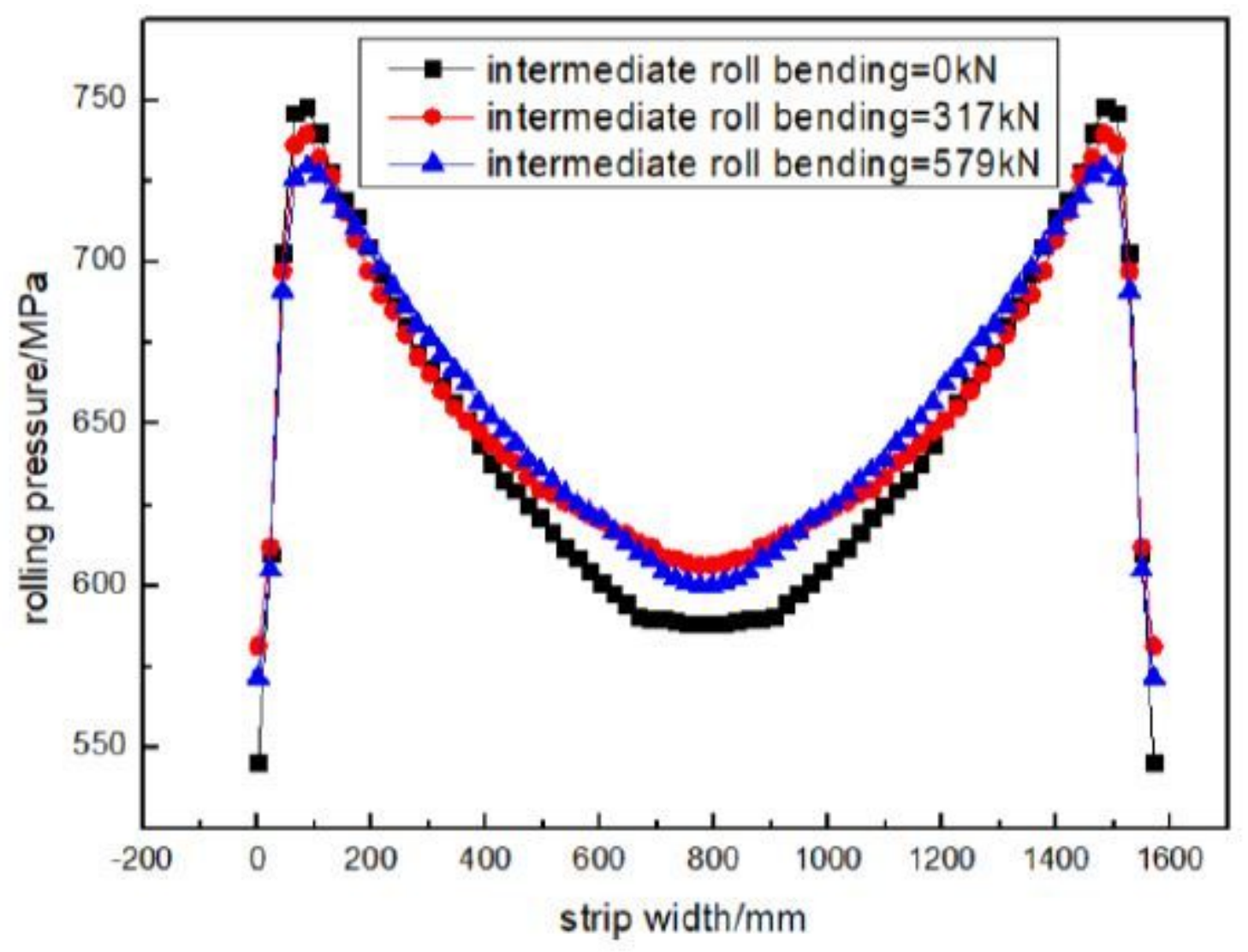

Figure 14

Distribution of rolling pressure along the strip width under different intermediate roll bending 


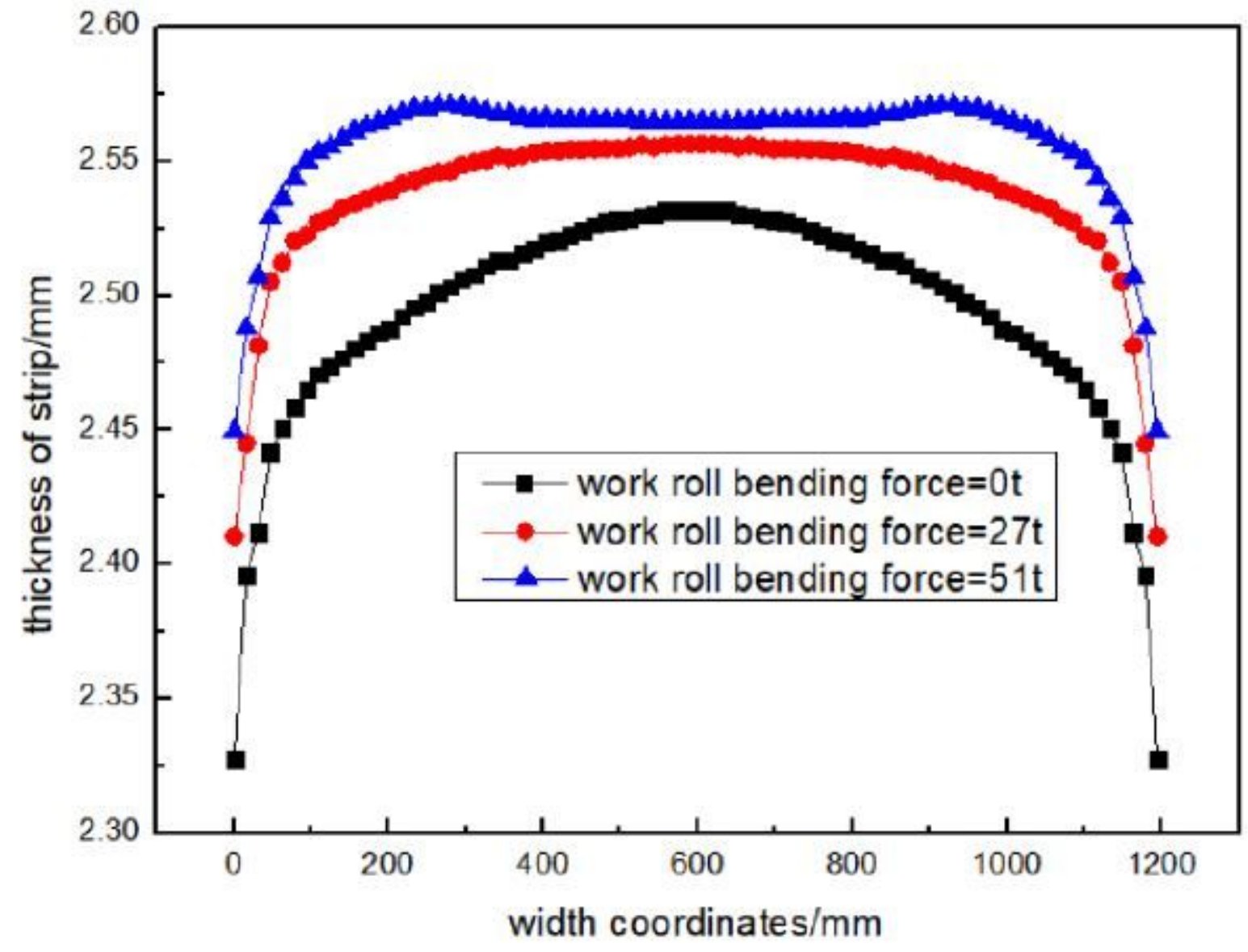

Figure 15

Lateral thickness distribution of strip steel for different work roll bending 


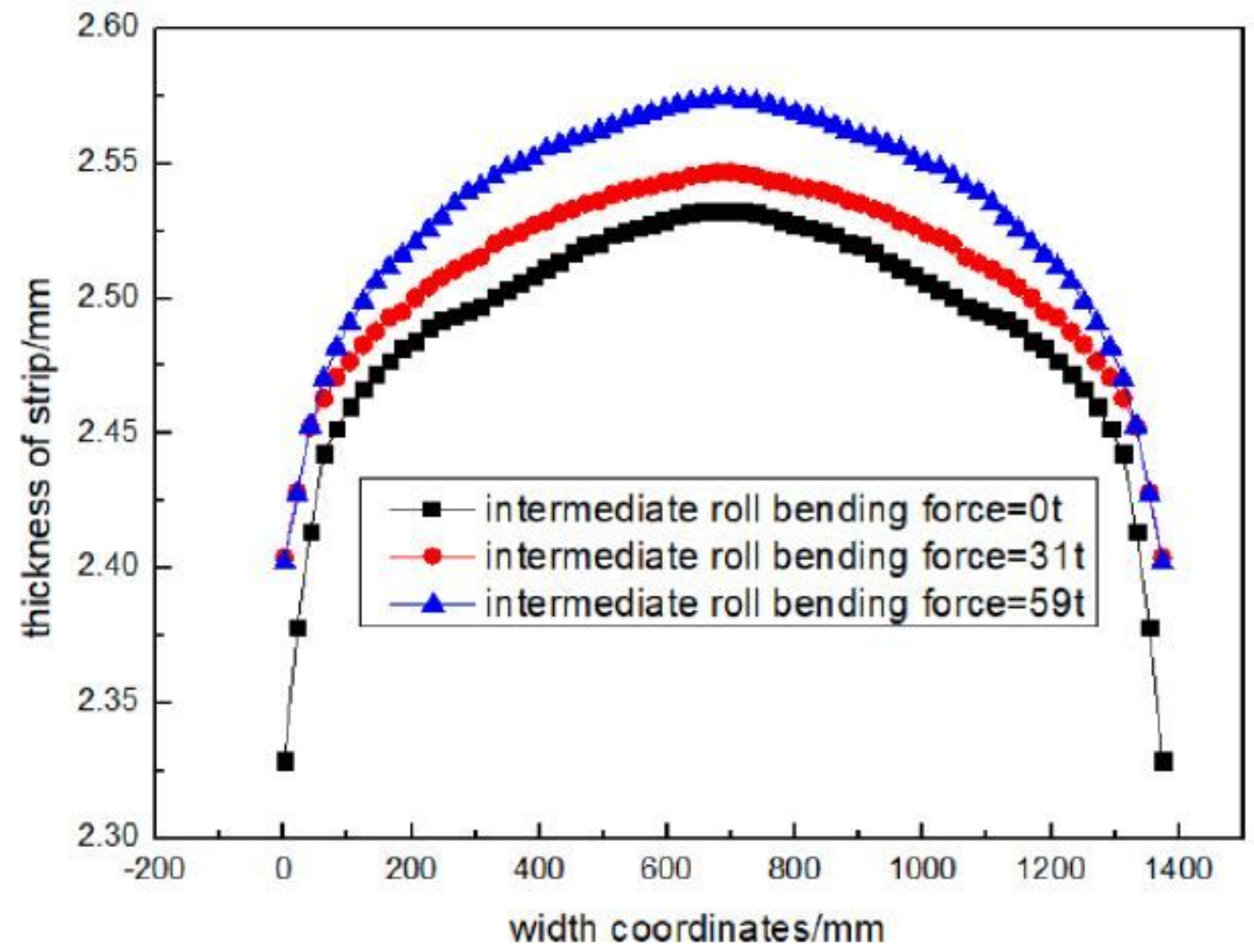

Figure 16

Lateral thickness distribution of strip steel under different intermediate roll bending 


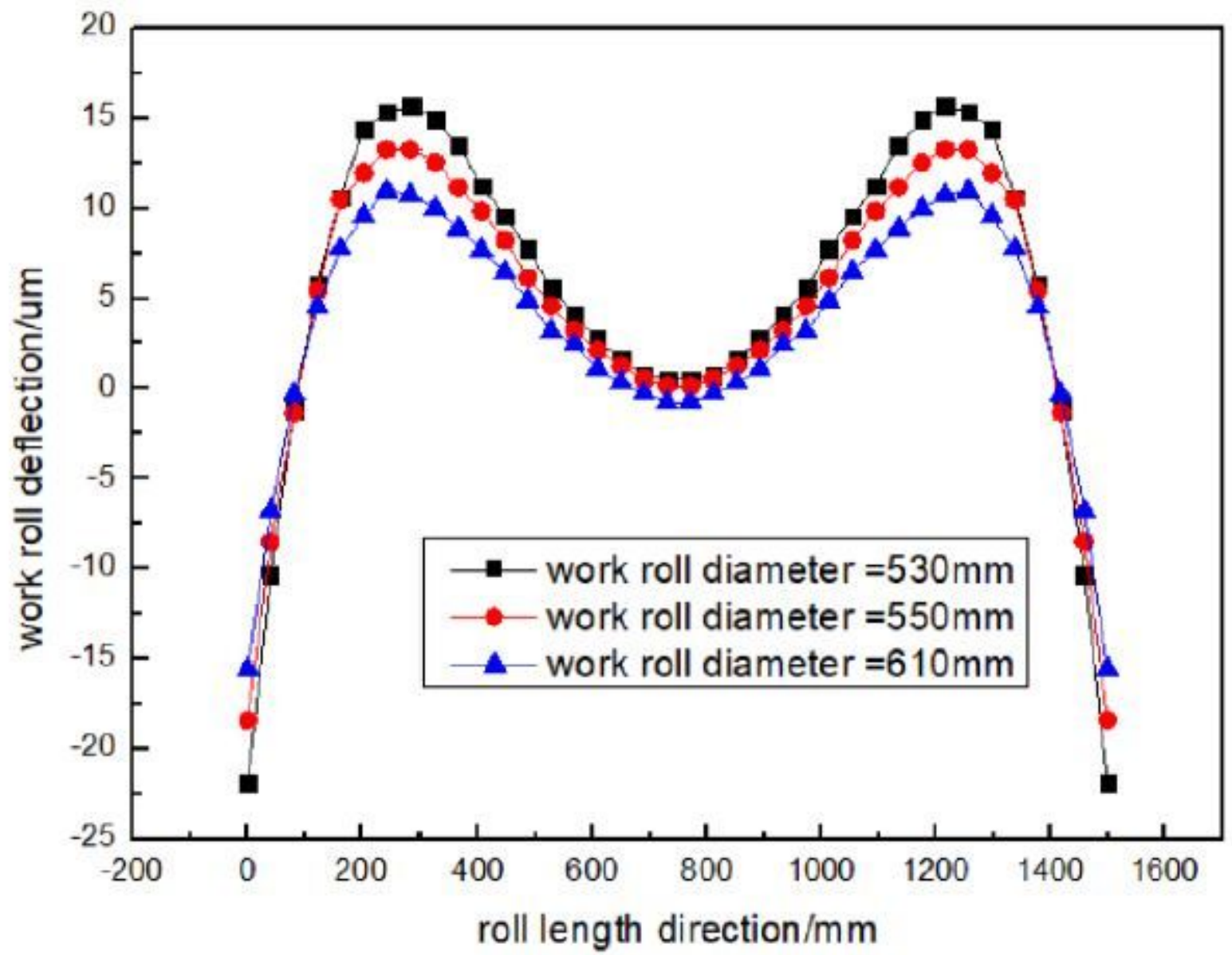

Figure 17

Work roll deflection distribution of different work roll diameters 


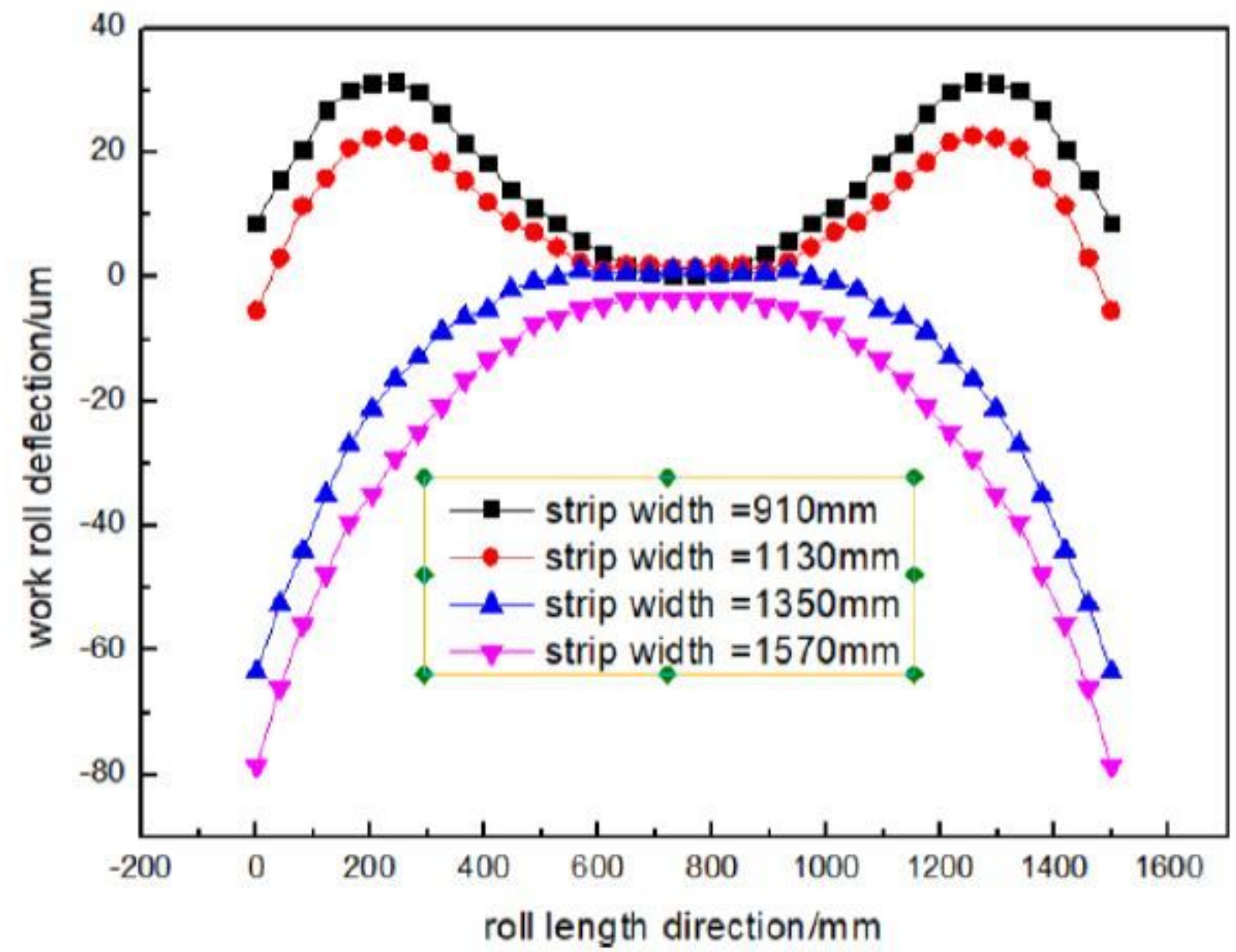

Figure 18

The deflection distribution of work roll with different strip widths 


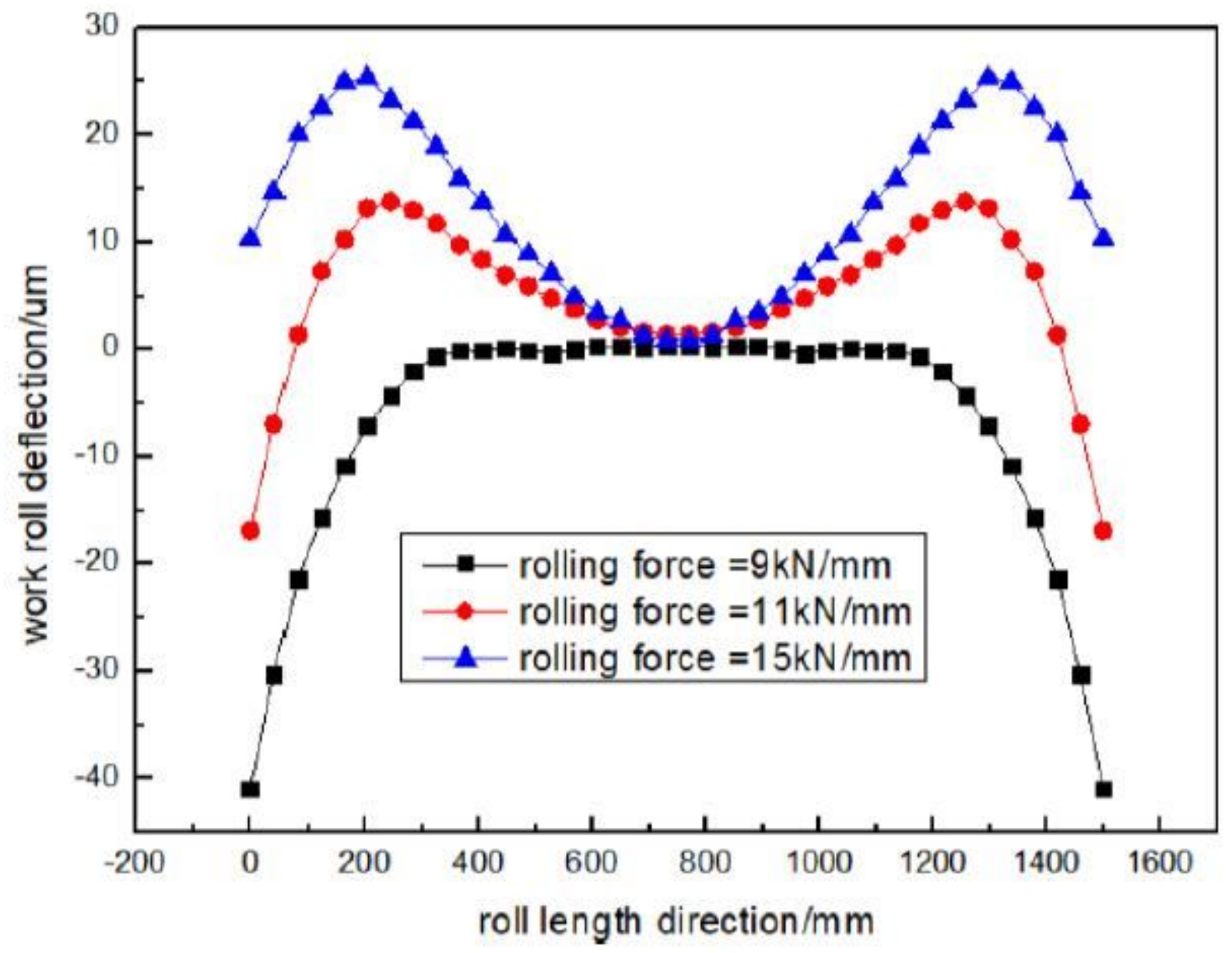

Figure 19

Deflection distribution of work roll with different rolling force 